\title{
Role of Bacillus licheniformis VS16-Derived Biosurfactant in Mediating Immune Responses in Carp Rohu and its Application to the Food Industry
}

\section{OPEN ACCESS}

Edited by:

Andrea Gomez-Zavaglia,

Center for Research and

Development in Food Cryotechnology

(CIDCA, CONICET), Argentina

Reviewed by:

George Seghal Kiran,

Pondicherry University, India

Kiiyukia Matthews Ciira,

Mount Kenya University, Kenya

*Correspondence:

Se Chang Park

parksec@snu.ac.kr

V. Sukumaran

drvsukumar@gmail.com

tPresent address:

V. Sukumaran,

Department of Zoology, Kundavai

Nachiyar Government Arts College

for Women (Autonomous), Thanjavur,

India

¥These authors share first authorship.

Specialty section:

This article was submitted to

Food Microbiology,

a section of the journal

Frontiers in Microbiology

Received: 21 November 2016 Accepted: 13 March 2017 Published: 28 March 2017

Citation:

Giri SS, Sen SS, Jun JW Sukumaran V and Park SC (2017) Role of Bacillus licheniformis

VS16-Derived Biosurfactant in Mediating Immune Responses in Carp Rohu and its Application to the Food Industry.

Front. Microbiol. 8:514. doi: 10.3389/fmicb.2017.00514

\author{
Sib Sankar Giri1,2‡, Shib Sankar Sen ${ }^{3 \neq}$, Jin Woo Jun², V. Sukumaran ${ }^{1 *+}$ and \\ Se Chang Park ${ }^{2 *}$
}

\begin{abstract}
' Department of Biotechnology, Periyar Maniammai University, Thanjavur, India, ${ }^{2}$ Laboratory of Aquatic Biomedicine, College of Veterinary Medicine and Research Institute for Veterinary Science, Seoul National University, Seoul, South Korea, ${ }^{3}$ School of Life Sciences, Jawaharlal Nehru University, New Delhi, India
\end{abstract}

Multifarious applications of Bacillus licheniformis VS16-derived biosurfactant were explored. Labeo rohita fingerlings were injected intraperitoneally with $0.1 \mathrm{~mL}$ of phosphate-buffered saline (PBS) containing purified biosurfactant at 0 (control), 55 (S55), 110 (S110), 220 (S220), or 330 (S330) $\mu \mathrm{g} \mathrm{mL} \mathrm{m}^{-1}$ concentrations. Various immunological parameters and the expression of immune-related genes were measured at 7, 14, and 21 days post-administration (dpa). At $21 \mathrm{dpa}$, fish were challenged with Aeromonas hydrophila and mortality was recorded for 14 days. Immune parameters such as lysozyme levels (39.29 $\left.\pm 2.14 \mathrm{U} \mathrm{mL}^{-1}\right)$, alternative complement pathway $\left(61.21 \pm 2.38 \mathrm{U} \mathrm{mL}^{-1}\right)$, and phagocytic activities $(33.37 \pm 1.2 \%)$ were maximum $(P<0.05)$ in the $\mathrm{S} 220$ group at $14 \mathrm{dpa}$; but immunoglobulin levels (11.07 $\pm 0.83 \mathrm{mg} \mathrm{mL}^{-1}$ ) were highest in the $\mathrm{S} 220$ group at $7 \mathrm{dpa}$, compared to that in controls. Activities of digestive enzymes (amylase, protease, and lipase) were higher $(P<0.05)$ in the S220 and S330 groups than in the control group. Regarding cytokine gene expression, pro-inflammatory cytokines (TNF- $\alpha$ and IL-1 $\beta$ ) were downregulated $(P<0.05)$ in the S220 and S330 groups. Expression of IL-10, TGF- $\beta$, and IKB- $\alpha$ were up-regulated in the S220 and S330 groups at $14 \mathrm{dpa}$, with the highest levels in the S220 group. The expression of NF-kB p65 and IKK- $\beta$ were downregulated in treatment groups, and were lowest $(P<0.05)$ in the $\mathrm{S} 220$ group. The highest post-challenge survival rate (72.7\%) was recorded in S220 group. Further, the potential of this substance to inhibit biofilm formation, and heavy metal removal from vegetables were also evaluated. Biosurfactant was effective in inhibiting biofilm formation up to $54.71 \pm 1.27 \%$. Moreover, it efficiently removed cadmium (Cd) from tested vegetables such as carrot, radish, ginger, and potato, with the highest removal efficiency (60.98 $\pm 1.29 \%$ ) recorded in ginger contaminated with $\mathrm{Cd}$. Collectively, these results suggest that isolated biosurfactant could be used in the aquaculture industry, in addition to its potential application to the food industry.

Keywords: Bacillus licheniformis VS16, biosurfactant, fish immune responses, immune-gene expression, disease resistance, heavy metal removal 


\section{INTRODUCTION}

'Biosurfactants are amphipathic surface active molecules consists of hydrophilic and hydrophobic moieties that act by emulsifying hydrocarbons, increasing their solubilization, and subsequently rendering them available for microbial degradation' (Donio et al., 2013). There are various classes of biosurfactants, among which the major classes are phospholipids, glycolipids, lipopolysaccharides, lipoproteins-lipopeptides, fatty acids, neutral lipids, flavolipids, the complete cell-surface itself, as well as those that are not fully characterized (Bodour et al., 2004). Microbial biosurfactants have numerous advantages over chemical surfactants, such as less toxic, higher biodegradability, environmentally compatible, higher foaming capability, high selectivity, specific activity at extreme $\mathrm{pH}$, temperatures, and salinity. Also, it can be synthesized from renewable food sources (Bezza and Chirwa, 2015). Recently, biosurfactants have been utilized in many unconventional fields, including the enhancement of oil recovery to reduce environmental impact during extraction, remediation of water insoluble pollutants, the replacement of traditional synthetic surfactants in healthcare, cosmetics, soap, and paints, and in the production and application of drug delivery systems (Omudu et al., 2014). Biosurfactants also exhibit anti-microbial, anti-tumor, and anti-inflammatory properties (Perfumo et al., 2010). Bacterial genera such as Bacillus, Pseudomonas, Halomonas, Acinetobacter, Arthrobacter, Rhodococcus, and Enterococcus have been reported to produce various types of biosurfactants (Satpure et al., 2010). The genus Bacillus consists of versatile microbial species that exhibit considerable biosurfactant production and produce cyclic lipopeptides and lipoproteins that include surfactins, fengicins, lichenysins, and bacillomycin as the major types biosurfactants (Mukherjee and Das, 2005; Swaathy et al., 2014).

Properties of biosurfactants including emulsion formation and stabilization, as well as anti-adhesive and antimicrobial activities, make them suitable for applications in food processing and formulation. The addition of rhamnolipid surfactants was shown to improve dough stability, texture, volume, and conservation of bakery products (Nitschke and Costa, 2007). A bioemulsifier isolated from Enterobacter cloacae was demonstrated as a potential viscosity improvement agent of interest to the food industry (Iyer et al., 2006). Streptococcus thermophilus derived surfactant has been used for fouling control of heat-exchanger plates in pasteurizers (Busscher et al., 1996). Further, a Pseudomonas fluorescens surfactant showed potential as an inhibitor of corrosion in stainless steel (Dagbert et al., 2006). In addition to its application to the food industry, recent studies have demonstrated that administration of microbial biosurfactants enhances the immune responses and disease resistance of fish (Giri et al., 2016c; Rajeswari et al., 2016). Therefore, potential applications of microbial surfactants in aquaculture need to be further exploited.

"Aquaculture has emerged as one of the most promising and fastest-growing industries with total global production rising to 66.63 million tons in 2012 from 63.6 million tons in 2011" (FAO, 2014). However, intensive aquaculture practices result in stress, poor water quality, poor nutritional status, overcrowding, and sudden changes in temperature. Further, widespread industrial developments have caused deteriorated aquatic environments (Giri et al., 2016a). Typically, antibiotics and chemotherapeutics are used to control diseases in aquatic animals. However, the overuse of such compounds results in the environmental hazards, food safety problems, and development of drug-resistant pathogens (Austin and Austin, 2007). Although vaccination has been used as an alternative strategy, a single vaccine is generally effective against only one type of pathogen (Pasnik et al., 2005). Recently, the application of probiotics has also received attention in aquaculture. However, one concern regarding its uses is antagonism with other beneficial bacteria, the possible development of virulence traits through horizontal gene transfer, and pathogenicity to humans (Sharifuzzaman et al., 2011). The limitations of antibiotics, chemotherapeutics, vaccines, and probiotics suggest that aquaculture disease management should emphasize on harmless, preventative, and lasting methods.

Fish primarily depends on their innate immune system (Uribe et al., 2011). They have mechanisms to protect them against foreign substances such as pathogens and toxins, among others. Recently, bacterial secondary metabolites have received greater attention for disease control in fish aquaculture. Liu et al. (2011) demonstrated that secondary metabolite cyclo-(L-Pro-Gly), isolated from Anoxybacillus flavithermus SX-4 could enhance non-specific immunity and disease resistance in carp (Cyprinus carpio). Isolated secondary metabolites from the soil isolate B. simplex increased cytokine responses and disease resistance against Aeromonas hydrophila challenge in C. carpio (Wang et al., 2011). Recently, Rajeswari et al. (2016) demonstrated that phospholipid biosurfactant from Staphylococcus hominis significantly enhanced specific and non-specific immunity as well as disease resistance in Oreochromis mossambicus. Therefore, screening for bacterial biosurfactants (secondary metabolites) might lead to the identification of an eco-friendly method to strengthen the fish immune system.

Lipopeptide biosurfactant production by various bacterial strains in solid state culture has been reported in various studies (Das and Mukherjee, 2007; Kiran et al., 2010b, 2014; Zouari et al., 2014). We previously showed that Bacillus subtilis VSG4, isolated from tropical soil (Oviya et al., 2012), produces biosurfactant that stimulates immune responses and cytokine gene expression in rohu (Labeo rohita), in addition to enhancing resistance to A. hydrophila infection in carp (Giri et al., 2016c). In the present study, a biosurfactant-producing strain, Bacillus licheniformis, was isolated from food waste. The effects of the extracted biosurfactant on immune responses and cytokine gene expression in L. rohita, and on disease resistance in carp were investigated. Furthermore, applications of the biosurfactant to the food industry were also studied.

\section{MATERIALS AND METHODS}

\section{Isolation and Enumeration of Bacterial Colonies}

Household food waste samples (mainly containing rice, vegetables, and fruits) were collected from Thanjavur city, Tamil 
Nadu, India, and serially diluted up to $10^{-7}$. One milliliter of sample from each dilution was spread-plated onto nutrient agar plates, which were incubated at $37^{\circ} \mathrm{C}$ for $48 \mathrm{~h}$. Morphologically diverse colonies were selected and stored at $4^{\circ} \mathrm{C}$ for further studies.

\section{Screening of Potential Biosurfactant-Producing Bacteria}

The following methods were adopted to screen potential biosurfactant-producing strains: (i) drop-collapse test, by adding mineral oil to 96-well microtiter plates (Rodrigues et al., 2006); (ii) oil displacement activity, by adding weathered crude oil (Anandaraj and Thivakaran, 2010); (iii) emulsification activity, by adding kerosene and an equal volume of cell-free supernatant (Deepak and Jayapradha, 2015). The most efficient biosurfactantproducing strain was selected for further studies.

\section{Identification of Bacterial Strain}

The morphological and biochemical characterization of the selected biosurfactant-producing strain was performed according to Bergey's Manual of Determinative Bacteriology, 9th edition (Holt et al., 1994). Molecular identification was performed by $16 \mathrm{~S}$ rRNA gene sequencing. Wizard ${ }^{\circledR}$ genomic DNA purification kit (Promega, Madison, WI, USA) was used for genomic DNA extraction. PCR amplification and sequencing of the 16S rRNA gene were carried out using universal primers (5'-GAGTTTGATCCTGGCTCAG-3'; 5'-AGAAAGGAGGTGA TCCAGCC- $3^{\prime}$ ). Sequences were compared to those of other $16 S$ RNAs obtained from GenBank using the BLAST program.

\section{Biosurfactant Production and Characterization}

The screened isolate was inoculated in $25 \mathrm{~mL}$ of sterile nutrient broth and incubated at $37^{\circ} \mathrm{C}$ for $24 \mathrm{~h}$ at $300 \mathrm{rpm}$. Biosurfactant production was carried out according to the method described earlier (Giri et al., 2016c). Briefly, $10 \mathrm{~mL}$ of inoculum was transferred to a 1-L conical flask containing $500 \mathrm{~mL}$ of previously described medium (Joshi et al., 2013) and incubated at $37^{\circ} \mathrm{C}$, $\mathrm{pH} 7.0$, and $300 \mathrm{rpm}$ for $72 \mathrm{~h}$. After adjusting the $\mathrm{pH}$ to 7.0, cultures were centrifuged at $11300 \times g$ at $4^{\circ} \mathrm{C}$ for $20 \mathrm{~min}$ to obtain cell-free supernatants. The supernatant was precipitated by adding $6 \mathrm{~N} \mathrm{HCl}$ and $\mathrm{pH}$ was adjusted to 2.0. The collected precipitate $\left(11300 \times g\right.$ at $4^{\circ} \mathrm{C}$ for $\left.20 \mathrm{~min}\right)$ was dissolved in $5 \mathrm{~mL}$ of distilled water and $\mathrm{pH}$ was adjusted to 7.0 with $1 \mathrm{~N} \mathrm{NaOH}$. The biosurfactant solution was dialysed against demineralised water at $4^{\circ} \mathrm{C}$ using a Cellu-Sep $\odot$ membrane (Seguin, USA) for $48 \mathrm{~h}$. The partially purified biosurfactant was freeze-dried and stored at $-20^{\circ} \mathrm{C}$ until use.

Initial identification of biosurfactant was performed using the phosphate (Okpokwasili and Ibiene, 2006) and biuret (Feigner et al., 1995) tests. Next, the partially purified biosurfactant was analyzed using a gas chromatography-mass spectrometry (GCMS) system (Shimadzu QP2010 Plus, Japan) equipped with a capillary column (DB-5 MS; 0.25-mm film thickness, $0.25 \mathrm{~mm}$ i.d., $30 \mathrm{~m}$ length) (Giri et al., 2016c). "Briefly, helium was used as the carrier gas with a flow rate of $1.0 \mathrm{~mL} \mathrm{~min} \mathrm{~m}^{-1}$. The injection port temperature was $250^{\circ} \mathrm{C}$. The column oven temperature was held at $80^{\circ} \mathrm{C}$ for $2 \mathrm{~min}$ and then the temperature was increased at every $10^{\circ} \mathrm{C} \mathrm{min}^{-1}$ up to $250^{\circ} \mathrm{C}$, after which the temperature was finally raised at a rate of $5^{\circ} \mathrm{C} \min ^{-1}$ to $280^{\circ} \mathrm{C}$; this temperature was held for $10 \mathrm{~min}$. Electron impact spectra were acquired in positive ionization mode between $\mathrm{m} / \mathrm{z} 40$ and $450^{\prime \prime}$ (Giri et al., 2016c).

The (cetyltrimethylammonium bromide) CTAB agar test (Siegmund and Wagner, 1991) was used to identify the type of surfactant, and the orcinol test (Chandrasekharan and Bemiller, 1980) was performed for the detection of reducing sugars. To estimate protein concentration, a Lowry test (Lowry et al., 1951) was performed. In addition, a phosphate test was performed to check for the presence of a phosphate moiety (Okpokwasili and Ibiene, 2006).

\section{Immunomodulatory Activities of Biosurfactant in L. rohita Experimental Plan}

Labeo rohita fingerlings (body weight: $21.47 \pm 1.06 \mathrm{~g}$ ) procured from a local fish farm were acclimatized to laboratory conditions for 2 weeks in $500-\mathrm{L}$ plastic tanks at $26 \pm 2^{\circ} \mathrm{C}$. Fish were fed the basal diet (Giri et al., 2016c) twice a day at a rate of $2 \%$ of their body weight. Basic physicochemical parameters of the water were measured weekly (American Public Health Association [APHA] et al., 2012). This study was conducted following the "Guidelines on the Regulation of Scientific Experiments on Animals," CPCSEA, GoI, and the experimental protocols were approved by the Institutional Ethics Committee of the Periyar Maniammai University.

The $\mathrm{LC}_{50}$ value of the biosurfactant in $L$. rohita was determined by acute toxicity testing as per the standard method (American Public Health Association [APHA] et al., 2012; Misik et al., 2012), starting with range-finding tests for acute toxicity trials. The $96-\mathrm{h} \mathrm{LC}_{50}$ of the biosurfactant in L. rohita was calculated as 2,650 $\mathrm{gg} \mathrm{mL}^{-1}$ using the Probit method (Finney, 1980). Sub-lethal concentrations $\left(55-330 \mu \mathrm{g} \mathrm{mL}^{-1}\right)$ were used in this study.

The fish were randomly distributed into five experimental groups, with three replicates in each group. Each tank contained 35 fish (i.e., per group: $35 \times 3=105$ fish) and tank capacity was 200 L. First four fish groups were injected intraperitoneally (i.p.) with $100 \mu \mathrm{L}$ of PBS containing the surfactant at concentrations of $55,110,220$, and $330 \mu \mathrm{g} \mathrm{mL}^{-1}$, and these groups were labeled 'S55, 'S110,' 'S220', and 'S330', respectively. The fifth group was injected with $100 \mu \mathrm{L}$ of PBS and considered as control. The fish were fed the basal diet and kept for observation until 21 days.

\section{Sample Collection and Immunological Parameters}

Nine fish $(3 \times 3=9$ fish per group $)$ were randomly collected from each group at 7, 14, and 21 days post administration (dpa). 'Blood samples were collected from the caudal vein using a 2-mL syringe after anesthetisation with MS222 (Sigma-Aldrich, St. Louis, MO, USA) and transferred to centrifuge tubes (Eppendorf, Germany).' Serum was collected by centrifugation $\left(4,000 \times g, 10 \mathrm{~min}, 4^{\circ} \mathrm{C}\right)$ and stored at $4^{\circ} \mathrm{C}$ until use' (Giri et al., 2015). Intestinal samples 
TABLE 1 | Real-time primer sequences and thermocycling conditions.

\begin{tabular}{|c|c|c|c|}
\hline Target gene & Primer sequence $\left(5^{\prime}-3^{\prime}\right)$ & Thermocycling conditions & Reference \\
\hline $\mathrm{TNF}-\alpha$ & $\begin{array}{l}\text { CTCAACAAGTCTCAGAACAATCAGG } \\
\text { TCCTGGTTCCTTCTCCAATCTAGCT }\end{array}$ & $\begin{array}{l}95^{\circ} \mathrm{C} 30 \mathrm{~s}, 40 \text { cycles of } 95^{\circ} \mathrm{C} 5 \mathrm{~s}, \\
61.1^{\circ} \mathrm{C} 30 \mathrm{~s}, \text { and } 72^{\circ} \mathrm{C} 30 \mathrm{~s}\end{array}$ & Giri et al., 2016c \\
\hline $\mathrm{IL}-1 \beta$ & $\begin{array}{l}\text { ATCTTGGAGAATGTGATCGAAGAG } \\
\text { GATACGTIITGATCCTCAAGTGTGAAG }\end{array}$ & $\begin{array}{l}95^{\circ} \mathrm{C} 30 \mathrm{~s}, 40 \text { cycles of } 95^{\circ} \mathrm{C} 5 \mathrm{~s}, \\
61.1^{\circ} \mathrm{C} 30 \mathrm{~s}, \text { and } 72^{\circ} \mathrm{C} 30 \mathrm{~s}\end{array}$ & Giri et al., 2016c \\
\hline $\mathrm{IL}-10$ & $\begin{array}{l}\text { AAGGAGGCCAGTGGCTCTGT } \\
\text { CCTGAAGAAGAGGCTCTGT }\end{array}$ & $\begin{array}{l}95^{\circ} \mathrm{C} 30 \mathrm{~s}, 40 \text { cycles of } 95^{\circ} \mathrm{C} 5 \mathrm{~s}, \\
61.1^{\circ} \mathrm{C} 30 \mathrm{~s}, \text { and } 72^{\circ} \mathrm{C} 30 \mathrm{~s}\end{array}$ & Giri et al., 2016c \\
\hline TGF- $\beta$ & $\begin{array}{l}\text { ACGCTTATTCCCAACCAAA } \\
\text { GAAATCCTTGCTCTGCCTCA }\end{array}$ & $\begin{array}{l}95^{\circ} \mathrm{C} 30 \mathrm{~s}, 40 \text { cycles of } 95^{\circ} \mathrm{C} 5 \mathrm{~s}, \\
60.5^{\circ} \mathrm{C} 30 \mathrm{~s}, \text { and } 72^{\circ} \mathrm{C} 30 \mathrm{~s}\end{array}$ & Giri et al., 2016c \\
\hline NF-кBp65 & $\begin{array}{l}\text { TATTCAGTGCGTGAAGAAG } \\
\text { TATTAAAGGGGTTGTTCTGT }\end{array}$ & $\begin{array}{l}95^{\circ} \mathrm{C} 30 \mathrm{~s}, 40 \text { cycles of } 95^{\circ} \mathrm{C} 5 \mathrm{~s}, 58^{\circ} \mathrm{C} \\
30 \mathrm{~s} \text {, and } 72^{\circ} \mathrm{C} 30 \mathrm{~s}\end{array}$ & Giri et al., 2016c \\
\hline IкB- $\alpha$ & $\begin{array}{l}\text { TCTTGCCATTATTCACGAGG } \\
\text { TGTTACCACAGTCATCCACCA }\end{array}$ & $\begin{array}{l}95^{\circ} \mathrm{C} 30 \mathrm{~s}, 40 \text { cycles of } 95^{\circ} \mathrm{C} 5 \mathrm{~s} \\
62.3^{\circ} \mathrm{C} 30 \mathrm{~s}, \text { and } 72^{\circ} \mathrm{C} 30 \mathrm{~s}\end{array}$ & Giri et al., 2016c \\
\hline $\mathrm{IKK} \beta$ & $\begin{array}{l}\text { GTGGCGGTGGATTATTGG } \\
\text { GCACGGGTTGCCAGTाTG }\end{array}$ & $\begin{array}{l}95^{\circ} \mathrm{C} 30 \mathrm{~s}, 40 \text { cycles of } 95^{\circ} \mathrm{C} 5 \mathrm{~s}, \\
60.3^{\circ} \mathrm{C} 30 \mathrm{~s}, \text { and } 72^{\circ} \mathrm{C} 30 \mathrm{~s}\end{array}$ & Giri et al., 2016c \\
\hline$\beta$-actin & $\begin{array}{l}\text { AGACCACCTTCAACTCCATCATG } \\
\text { TCCGATCCAGACAGAGTATTTACGC }\end{array}$ & $\begin{array}{l}95^{\circ} \mathrm{C} 30 \mathrm{~s}, 40 \text { cycles of } 95^{\circ} \mathrm{C} 5 \mathrm{~s}, \\
60.5^{\circ} \mathrm{C} 30 \mathrm{~s}, \text { and } 72^{\circ} \mathrm{C} 30 \mathrm{~s}\end{array}$ & Giri et al., 2016c \\
\hline
\end{tabular}

from the fish were dissected aseptically, rinsed with cold distilled water, and used for the analysis of intestinal enzyme activities.

Head kidney macrophages were isolated $(3 \times 3=9$ fish per group) according to the method described by Li et al. (2013). Trypan blue exclusion test was used to evaluate the cell viability and cell concentration was measured using a haemocytometer. Harvested cells were adjusted to a concentration of $1 \times 10^{7}$ cells $\mathrm{mL}^{-1}$ for further use.

\section{Immune parameters}

Serum lysozyme activity (LA) and alternative complement pathway (ACP) activity was determined according to the methods described by Ellis (1990) and Yano (1992), respectively Phagocytic activity (PA) of head kidney macrophages was determined using the method descried by Geng et al. (2012). The number of phagocytic cells per 100 adherent cells was microscopically determined. The PA was calculated following the formula: $\mathrm{PA}=$ (phagocytic leucocytes/total leucocytes $) \times 100$. Serum bactericidal activity against $A$. hydrophila was tested as described by Welker et al. (2007). Serum immunoglobulin (IgM) levels were measured according to a previously described method (Giri et al., 2016b).

\section{Intestinal Enzyme Activities}

Amylase activity was assayed by the method described by Furné et al. (2005); protease activity was assayed as described by Anson (1938); lipase activity was determined using the method reported by Mckellar and Cholette (1986). All enzymatic activities were expressed as specific activity $\left(\mathrm{U} \mathrm{mg}^{-1}\right.$ protein).

\section{Gene Expression Analysis}

The head kidney from nine fish per group was dissected at 7 , 14, and $21 \mathrm{dpa}$. "Total RNA was extracted using TRIzol reagent (Invitrogen, USA) according to the manufacturer's instructions. Total RNA concentration and purity were determined using a spectrophotometer, and the quality was checked by agarose gel electrophoresis. The extracted RNA was treated with RNA-Free DNase (Takara, Shiga, Japan) to remove contaminating DNA and then reverse transcribed into cDNA using a Superscript cDNA synthesis kit (Life Technologies) following the manufacturer's instructions" (Giri et al., 2015). Real-time PCR analysis of TNF$\alpha$, IL-1 $\beta$, IL-10, IL-12, TGF- $\beta$, NF- $\kappa$ B p65, IKK- $\beta$, IкB- $\alpha$, and $\beta$-actin mRNA expression was performed using the CFX96 ${ }^{\mathrm{TM}}$ Real-Time PCR platform (Bio-Rad) following standard protocols with the primers and thermo-cycling conditions indicated in Table 1. Carp specific primers were used in this study, and the sequences were selected from the literature (Giri et al., 2016c). "All PCRs were performed at least three times. To verify the accuracy of each reaction, we performed melting curve analysis and checked the dissociation curve after amplification. $\beta$-Actin was used as an endogenous control for data analysis. All samples were run in parallel with the housekeeping gene, which was used to normalize cDNA loading" (Giri et al., 2015). Gene expression results were analyzed using the $2^{-\Delta \Delta C T}$ method after verification that the primers amplified with an efficiency of approximately $100 \%$ (Livak and Schmittgen, 2001); data for all treatment groups were compared to those of the control group.

\section{Pathogen Challenge Test}

At the end of the 21-days trial, 36 fish from every group (including the control group) were injected with $100 \mu \mathrm{L}$ of PBS containing $1 \times 10^{7}$ live $A$. hydrophila. The dose was determined based on a preliminary study. For negative control, another 30 fish (fed on a basal diet during the trial) were injected with $100 \mu \mathrm{L}$ of PBS. The daily mortality of the challenged fish was recorded for 14 days. The relative percentage survival (RPS, \%) was calculated using the formula of Amend (1981) as follows: RPS $=(1-\%$ mortality in treated group/\% mortality in control group) $\times 100$.

\section{Heavy Metal Removal from Vegetables}

Vegetables such as potato, carrot, radish, and ginger were collected from the local market of Thanjavur, Tamil Nadu. Vegetables were washed thoroughly with running tap water for 30-40 min and then washed with double distilled water. The skins were removed, cut into small pieces, immersed in a $1: 1 \mathrm{HCl}$ 
solution for $10 \mathrm{~min}$, and then washed with double deionised water (Anjum et al., 2016).

Cadmium chloride stock solution was prepared in milli-Q water at a concentration of $1000 \mathrm{mg} \mathrm{L}^{-1}$. A violet color developed when diphenylcarbazide was added and the absorbance was then determined at $540 \mathrm{~nm}$ using a UV-VIS spectrometer and a standard curve was plotted.

Vegetables were exposed to cadmium chloride at concentrations of $0.3,0.4$, and $0.5 \mathrm{mg} \mathrm{mL}^{-1}$ for $30 \mathrm{~min}$ and diphenylcarbazide was added to develop the violet color (Anjum et al., 2016). The absorption of the Cd ion concentration was determined using a UV-VIS spectrophotometer. Few of the vegetables from the same stock were treated with biosurfactant; after the absorption with cadmium chloride, the change in concentration was again determined by measuring the OD at $540 \mathrm{~nm}$. The cadmium ion removal percentage due to bio-adsorption was calculated as: percent $\mathrm{Cd}$ removal $=\left(\mathrm{C}_{\mathrm{i}}-\right.$ $\left.\mathrm{Co} / \mathrm{C}_{\mathrm{i}}\right) \times 100$, where $\mathrm{C}_{\mathrm{i}}=$ initial concentration of cadmium $(\mathrm{mg}$ $\left.\mathrm{L}^{-1}\right)$ and $\mathrm{Co}=$ final concentration of cadmium $\left(\mathrm{mg} \mathrm{L}^{-1}\right)$.

\section{Biofilm Inhibition Assay}

Biofilm inhibition assay was performed following the previously described method of Anjum et al. (2016) with slight modification. Overnight culture of Escherichia coli was prepared in 96-well plates containing $100 \mu \mathrm{L} \mathrm{LB}$ medium per well $\left(37^{\circ} \mathrm{C}, 200 \mathrm{rpm}\right)$. After 20 h, a 96-pin replicator (Boekel Scientific) was applied to inoculate 96 -well test plates containing $150 \mu \mathrm{L}$ of relevant preheated medium. To avoid the evaporation of medium, test plates were transferred to large plastic bags and incubated at $37^{\circ} \mathrm{C}$ for
$48 \mathrm{~h}$ without shaking. After $48 \mathrm{~h}$, biofilm was formed in a 96well microtiter plate. The supernatant was discarded and the wells were washed with PBS to remove non-adherent cells. Then, the biofilm was treated with biosurfactant along with the control. The plates were incubated at $37^{\circ} \mathrm{C}$ for $2 \mathrm{~h}$ and $4 \mathrm{~h}$. Subsequently, the plates were washed twice to remove non-adherent cells. A $100-\mu \mathrm{L}$ solution of $0.4 \%$ crystal violet was added, incubated for $30 \mathrm{~min}$, and washed with PBS to remove the extra stain. The biofilm was air dried for $5 \mathrm{~min}$, then absolute ethanol was added to solubilize the crystal violet. The optical density was determined using a spectrophotometer (Perkin-Elmer, USA) at $590 \mathrm{~nm}$.

\section{Statistical Analysis}

Analysis of variance (ANOVA) tests were used to analyze the data. A Tukey's test was used to analyze differences between the treatments. The OriginPro software (version 8; OriginLab Corporation, Northampton, MA, USA) was used for statistical analysis. The significance level fixed at $P<0.05$. Results were expressed as the mean \pm SEM.

\section{RESULTS}

\section{Isolation and Screening of Biosurfactant-Producing Bacteria}

Eighteen different bacterial colonies were selected from nutrient agar plates, of which eight isolates exhibited positive haemolysis activity. Among them, strain VS16 exhibited the highest haemolytic activity in terms of zone of clearance $(2.97 \mathrm{~cm}$ radius)

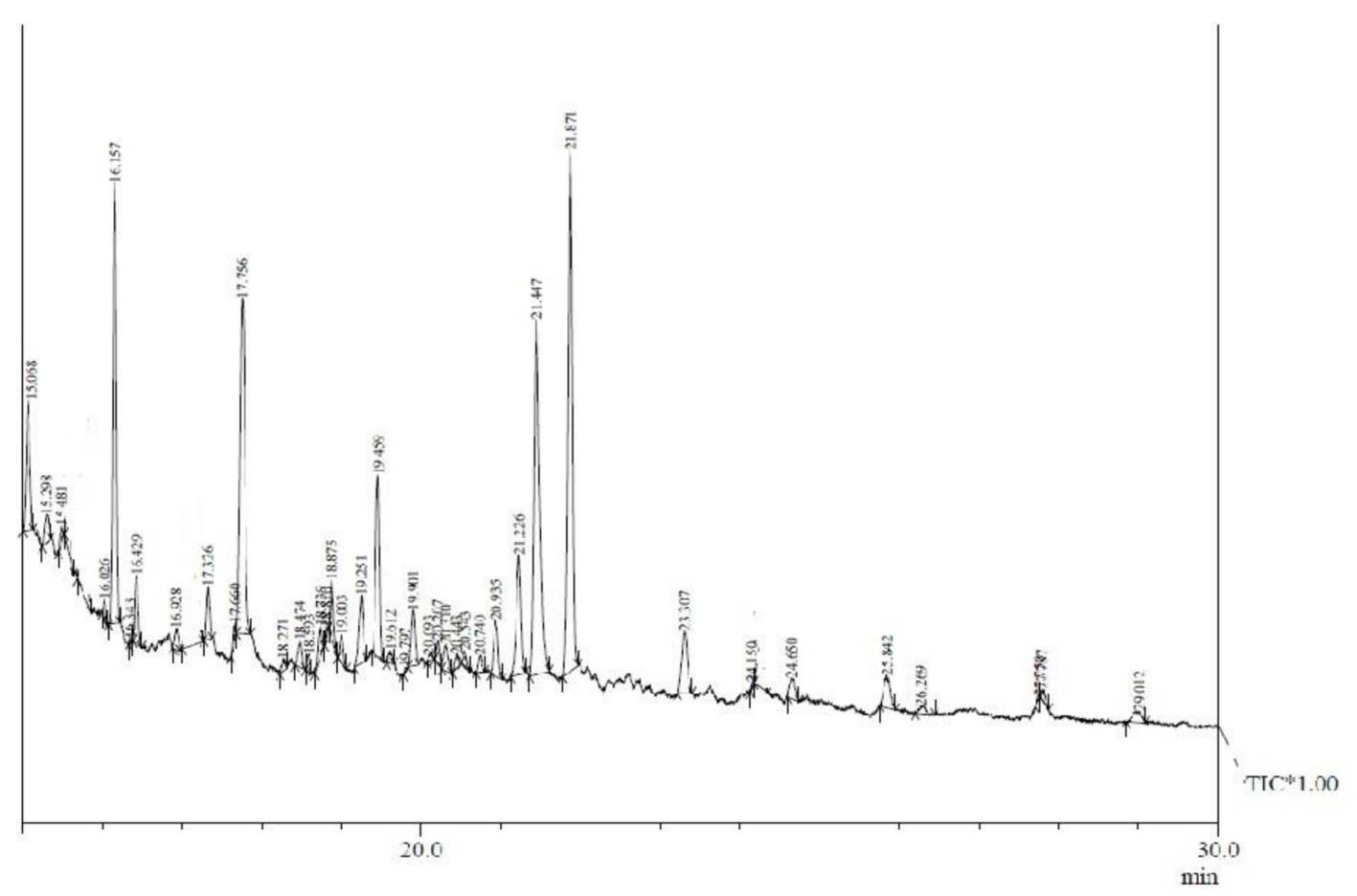

FIGURE 1 | Gas chromatography-mass spectrometry (GC-MS) analysis of partially purified Bacillus licheniformis VS16-derived biosurfactant. 
TABLE 2 | Compounds identified from Bacillus licheniformis VS16 derived biosurfactant by gas chromatography-mass spectrometry (GC-MS) analysis.

\begin{tabular}{|c|c|c|c|c|c|}
\hline SI no & $\begin{array}{c}\text { Retention } \\
\text { time }\end{array}$ & Name of the compounds & $\begin{array}{c}\text { Molecular } \\
\text { formula }\end{array}$ & $\begin{array}{l}\text { Molecular } \\
\text { weight (Da) }\end{array}$ & $\begin{array}{c}\text { Peak } \\
\text { area \% }\end{array}$ \\
\hline 1 & 15.06 & 9- Hexadecenoic acid, methyl ester & $\mathrm{C}_{16} \mathrm{H}_{30} \mathrm{O}_{2}$ & 254 & 4.17 \\
\hline 2 & 16.15 & Eicosanoic acid, methyl ester & $\mathrm{C}_{21} \mathrm{H}_{42} \mathrm{O}_{2}$ & 326 & 13.62 \\
\hline 3 & 17.75 & Heptacosane & $\mathrm{C}_{27} \mathrm{H}_{56}$ & 380 & 14.3 \\
\hline 4 & 19.25 & Heneicosane & $\mathrm{C}_{21} \mathrm{H}_{44}$ & 296 & 2.40 \\
\hline 5 & 19.45 & Octadecanoic acid, methyl ester & $\mathrm{C}_{19} \mathrm{H}_{38} \mathrm{O}_{2}$ & 298 & 5.87 \\
\hline 6 & 20.93 & Myristoleic acid & $\mathrm{C}_{14} \mathrm{H}_{26} \mathrm{O}_{2}$ & 226 & 2.132 \\
\hline 7 & 21.22 & Pentadecanoic acid & $\mathrm{C}_{15} \mathrm{H}_{30} \mathrm{O}_{2}$ & 242 & 4.74 \\
\hline 8 & 21.44 & Tert-hexadecanoic acid & $\mathrm{C}_{16} \mathrm{H}_{34} \mathrm{~S}$ & 258 & 18.16 \\
\hline 9 & 21.87 & Hexadecanoic acid, methyl ether & $\mathrm{C}_{17} \mathrm{H}_{34} \mathrm{O}_{2}$ & 270 & 21.76 \\
\hline 10 & 23.30 & Myristic acid, methyl ester & $\mathrm{C}_{14} \mathrm{H}_{28} \mathrm{O}_{2}$ & 232 & 2.91 \\
\hline 11 & 25.84 & Mannosamine & $\mathrm{C}_{6} \mathrm{H}_{13} \mathrm{NO}_{5}: \mathrm{HCl}$ & 215.6 & 1.79 \\
\hline
\end{tabular}

TABLE 3 | Lysozyme activity (LA) and alternative complement pathway (ACP) activities in Labeo rohita administered (i.p) with purified biosurfactant.

\begin{tabular}{|c|c|c|c|c|c|c|}
\hline \multirow[t]{2}{*}{ Group } & \multicolumn{3}{|c|}{$\mathrm{LA}\left(\mathrm{U} \mathrm{mL}^{-1}\right)$} & \multicolumn{3}{|c|}{$\mathrm{ACP}\left(\mathrm{ACH}_{50} \mathrm{U} \mathrm{mL}^{-1}\right)$} \\
\hline & 7 days & 14 days & 21 days & 7 days & 14 days & 21 days \\
\hline Control & $28.31 \pm 1.04^{a}$ & $28.79 \pm 1.13^{a}$ & $28.46 \pm 0.81^{a}$ & $47.31 \pm 1.96^{a}$ & $48.06 \pm 2.11^{a}$ & $47.83 \pm 1.73^{a}$ \\
\hline $55 \mu \mathrm{g} \mathrm{mL}^{-1}$ & $28.38 \pm 0.93^{a}$ & $29.94 \pm 1.02^{\mathrm{ab}}$ & $31.87 \pm 1.14^{a b}$ & $49.14 \pm 2.10^{a b}$ & $48.68 \pm 1.86^{a b}$ & $49.73 \pm 1.38^{a}$ \\
\hline $110 \mu \mathrm{g} \mathrm{mL}^{-1}$ & $32.96 \pm 1.64^{b}$ & $34.61 \pm 1.72^{\mathrm{bc}}$ & $31.97 \pm 0.86^{a b}$ & $50.57 \pm 2.48^{a b}$ & $54.37 \pm 1.73^{\mathrm{bc}}$ & $53.11 \pm 2.06^{b c}$ \\
\hline $220 \mu \mathrm{g} \mathrm{mL}^{-1}$ & $35.83 \pm 1.27^{\mathrm{bc}}$ & $39.29 \pm 2.14^{c}$ & $35.02 \pm 1.82^{b}$ & $53.78 \pm 1.82^{b}$ & $61.21 \pm 2.38^{\mathrm{c}}$ & $56.47 \pm 1.62^{\mathrm{C}}$ \\
\hline $330 \mu \mathrm{g} \mathrm{mL}^{-1}$ & $37.92 \pm 1.39^{c}$ & $34.98 \pm 1.62^{\mathrm{bc}}$ & $32.65 \pm 1.37^{\mathrm{ba}}$ & $54.19 \pm 1.93^{\mathrm{b}}$ & $57.02 \pm 1.57^{c}$ & $54.71 \pm 2.14^{c}$ \\
\hline
\end{tabular}

Values in the same column with different superscripts letters are significantly different $(P<0.05)$. Values are presented as mean $\pm S E M(n=9)$.

on blood agar. Emulsion formation is the stable interaction between the hydrophobic and hydrophilic phases. Among the isolates, VS16 had highest emulsification index of $49.03 \%$ during the tropophase and hence was selected for further studies. Results of the drop collapse and oil displacement tests confirmed that VS16 is highly capable of producing biosurfactant. Hence, VS16 was used for further studies.

Strain VS16 consisted of gram-positive, rod shaped bacteria that were arranged as chains. The results of biochemical tests indicated that the isolate was similar to Bacillus spp. Phenotypic identification was confirmed by $16 \mathrm{~S}$ rRNA gene sequence analysis. BLAST search analysis ${ }^{1}$ of the obtained 16S rRNA sequence (629 bp) showed high identity scores when compared to sequences from the Bacillus genus. Strain VS16 had the highest nucleotide sequence similarity value (99\%) when compared to that of B. licheniformis (GenBank accession numbers: KJ526872.1, KF737353.1, AY842876.1, and AY859479.1) (Phylogenetic data not shown). The nucleotide sequence of this strain has been submitted to NCBI GenBank under the accession number KX943303.

\section{Biosurfactant Production and Characterization}

The result of CTAB showed no coloration of colonies or of CTAB agar, which indicates that the biosurfactant was not a glycolipid. Based on the Orcinol test, the expected red-orange coloration was not observed, indicating the absence of reducing sugars in the

\footnotetext{
${ }^{1}$ https://www.ncbi.nlm.nih.gov/blast/
}

biosurfactant. The partially purified biosurfactant tested positive using Lowry's test, thus indicating the presence of a lipopeptide moiety. Moreover, a phosphate assay confirmed its phospholipid type. These results demonstrated that the B. licheniformis VS16derived biosurfactant could be a type of phospho-lipopeptide biosurfactant.

Gas chromatography-mass spectrometry analysis (Figure $\mathbf{1}$ and Table 2) revealed the presence of 11 lipid-based compounds with biosurfactant properties. Major peaks at retention times of $16.15,17.75,21.44$, and $21.87 \mathrm{~min}$ were confirmed as eicosanoic acid, heptacosane, tert-hexadecanoic acid, and hexadecanoic acid, with molecular weights of 326, 380, 258, and $270 \mathrm{Da}$, respectively. Similarly, heneicosane, octadecanoic acid and methyl ester, myristoleic acid, and pentadecanoic acid were identified at the retention times of 19.25, 19.45, 20.93, and 21.22 min with molecular weight (Da) of 296, 298, 226, and 242 , respectively. Peaks at $15.06,23.30$, and 25.84 min were confirmed as 9-hexadecenoic acid, methyl ester, myristic acid, methyl ester, and mannosamine with molecular weights of 254, 232, and 215.6, respectively. The highest percentage of peak area was for hexadecanoic acid and the lowest percentage peak $(2.91 \%)$ was identified for myristoleic acid at a retention time of $20.93 \mathrm{~min}$.

\section{Effect of Biosurfactant on Immune Responses in L. rohita}

The highest LA and ACP activities $(P<0.05)$ were recorded 14 days in S220 group (Table 3). However, both LA and ACP 
activities slightly declined at 21 days, when compared to those recorded at 14 days, except in the 555 group.

Significantly higher PA was recorded in the S220 and S330 groups than in the control group at all time points (Table 4), with highest in the S220 group at 14 days. IgM levels were higher in the treated groups (Table 4). Fish in the S220 group exhibited significantly higher IgM levels at all time points, with a highest in the S220 group at 7 days (Table 4).

\section{Effect of Biosurfactant on Digestive Enzyme Activities in L. rohita}

Administration (i.p.) of biosurfactant enhanced digestive enzyme activities in fish (Table 5). Amylase activity was significantly higher in the S220-S330 groups at 14 and 21 dpa than in the controls, and was highest in the S220 group at $14 \mathrm{dpa}$. Protease activity was significantly higher in the S220 group at 14 and 21 dpa with the highest levels at $14 \mathrm{dpa}$. Lipase activity was higher $(P<0.05)$ in the S220 and S330 groups at 14 and 21 dpa (Table 5); however, highest lipase activity was recorded in the S330 group at $7 \mathrm{dpa}$.

\section{Effect of Biosurfactant on Cytokine Gene Expression}

The expression of cytokine genes in the head kidney of L. rohita was altered by biosurfactant administration (i.p.) as shown in Figures 2-4.

Fish administered biosurfactant (S110-S330) had significantly lower TNF- $\alpha$ levels at 14 dpa (Figure 2) when compared to those in the controls, with the lowest levels observed in the S220 group. At 7 dpa, lower $(P<0.05)$ TNF- $\alpha$ expression was recorded in the S330 group. The expression of IL-1 $\beta$ was lower in the treatment groups and differences were significant in the S220 and S330 groups at 7 and $14 \mathrm{dpa}$ (Figure 2).

Administration of biosurfactant to fish provoked the expression of anti-inflammatory cytokines IL-10 and TGF$\beta$ during the whole experimental period (Figure 3). IL-10 expression was higher $(P<0.05)$ in the $\mathrm{S} 110-\mathrm{S} 330$ groups at 14 dpa, with the highest levels in the S220 group. TGF- $\beta$ mRNA expression was significantly higher in the S220 and S330 groups at 7 and 14 dpa. However, both IL-10 and TGF- $\beta$ showed a declining tendency at $21 \mathrm{dpa}$.

The expression of NF- $\mathrm{KB}$ p 65 showed a tendency to decline in the treated groups at all time points (Figure 4). NF- $\kappa \mathrm{B}$ p65 expression was significantly lower in the S110-S330 groups at 14 dpa. At 7 and $21 \mathrm{dpa}$, differences were significant only for the S330 and S110 groups, respectively.

Fish treated with biosurfactant tended to exhibit lower IKK $\beta$ expression than those in the control groups at all time points, but the differences were significant only for the S220 group at 14 dpa (Figure 4). IкB- $\alpha$ expression was significantly higher in the S110-S330 groups at 14 dpa (Figure 4) than in the controls, with the highest expression in the S220 group. At 21 dpa, significantly higher IкB- $\alpha$ expression was recorded in the S220 group.

\section{Pathogen Challenge Test}

The results of the challenge study revealed that fish administered biosurfactant exhibited better protection against $A$. hydrophila infection. Fish administered $220 \mu \mathrm{g} \mathrm{mL}^{-1}$ of biosurfactant (S220) exhibited the highest RPS (72.72\%), which was followed by fish in the S330 (57.56\%), S110 (39.39\%), and S55 (12.11\%) groups. No mortality was observed in the negative control group. The lowest survival $(8.33 \%)$ was recorded in the positive control group.

\section{Biofilm Inhibition and Heavy Metal Removal Efficiency}

Bacillus licheniformis VS16-derived biosurfactant was effective in inhibiting biofilm formation, and in removing heavy metals from vegetables (Table 6). The biofilm inhibition study showed that the biosurfactant was effective in suppressing biofilm formation by up to $54 \%$ (Table $6 \mathbf{A}$ ). Further, the biosurfactant had the potential to remove cadmium from carrots, radishes, ginger, and potatoes (Table 6B). Biosurfactant removed $60.98 \%$ of $\mathrm{Cd}$ from Cd-contaminated ginger.

\section{DISCUSSION}

\section{Biosurfactant Composition}

Biosurfactant production by B. licheniformis VS16 was confirmed through several simple yet powerful screening methods such as emulsification activity, drop collapse test, and oil displacement tests. The composition of biosurfactant was characterized through GC-MS analysis (Figure 1 and Table 2). The percentages of peak area were $13.62,14.3,18.16$, and $21.76 \%$ for eicosanoic acid, heptacosane, tert-hexadecanethiol, and hexadecanoic acid, respectively. The highest percentage of peak area was available for

TABLE 4 | Phagocytic activity (PA) and immunoglobulin M (IgM) activities in L. rohita administered (i.p) with purified biosurfactant.

\begin{tabular}{|c|c|c|c|c|c|c|}
\hline \multirow[t]{2}{*}{ Group } & \multicolumn{3}{|c|}{ PA (\%) } & \multicolumn{3}{|c|}{$\lg M\left(m g ~ m L^{-1}\right)$} \\
\hline & 7 days & 14 days & 21 days & 7 days & 14 days & 21 days \\
\hline Control & $17.26 \pm 0.47^{a}$ & $17.84 \pm 0.52^{a}$ & $16.93 \pm 0.39^{a}$ & $6.82 \pm 0.41^{a}$ & $6.78 \pm 0.53^{a}$ & $6.91 \pm 0.38^{a}$ \\
\hline $55 \mu \mathrm{g} \mathrm{mL}^{-1}$ & $18.64 \pm 0.72^{a b}$ & $19.23 \pm 0.31^{a}$ & $18.82 \pm 0.26^{a}$ & $7.63 \pm 0.48^{a}$ & $8.11 \pm 0.36^{a c}$ & $8.37 \pm 0.62^{a b}$ \\
\hline $110 \mu \mathrm{g} \mathrm{mL}^{-1}$ & $22.73 \pm 0.81^{b c}$ & $26.18 \pm 0.59^{b}$ & $22.96 \pm 0.74^{\mathrm{ac}}$ & $8.16 \pm 0.37^{a b}$ & $9.68 \pm 0.71^{\mathrm{bc}}$ & $9.48 \pm 0.43^{b}$ \\
\hline $220 \mu \mathrm{g} \mathrm{mL}^{-1}$ & $25.18 \pm 0.62^{\mathrm{c}}$ & $33.37 \pm 1.20^{c}$ & $28.13 \pm 1.3^{\mathrm{bc}}$ & $11.07 \pm 0.83^{b}$ & $10.57 \pm 0.62^{b}$ & $8.96 \pm 0.72^{b c}$ \\
\hline $330 \mu \mathrm{g} \mathrm{mL}^{-1}$ & $26.74 \pm 1.03^{c}$ & $30.24 \pm 0.79^{b c}$ & $26.98 \pm 1.07^{c}$ & $10.74 \pm 0.52^{b}$ & $8.62 \pm 0.92^{\mathrm{ba}}$ & $6.93 \pm 0.46^{\mathrm{ac}}$ \\
\hline
\end{tabular}

Values in the same column with different superscripts letters are significantly different $(P<0.05)$. Values are presented as mean $\pm S E M(n=9)$. 
TABLE 5 | Digestive enzyme activities of $L$. rohita administered with biosurfactant.

\begin{tabular}{|c|c|c|c|c|}
\hline \multirow[t]{2}{*}{ Parameters } & \multirow[t]{2}{*}{ Doses of biosurfactant } & \multicolumn{3}{|c|}{ Enzyme activities } \\
\hline & & 7 days & 14 days & 21 days \\
\hline \multirow[t]{5}{*}{ Amylase } & $0 \mu \mathrm{g} \mathrm{mL}^{-1}$ & $7.03 \pm 0.13^{a}$ & $7.06 \pm 0.08^{a}$ & $7.08 \pm 0.11^{\mathrm{a}}$ \\
\hline & $55 \mu \mathrm{g} \mathrm{mL}^{-1}$ & $7.07 \pm 0.10^{\mathrm{a}}$ & $7.14 \pm 0.09^{a b}$ & $7.21 \pm 0.13^{a}$ \\
\hline & $110 \mu \mathrm{g} \mathrm{mL}^{-1}$ & $8.26 \pm 0.17^{a b}$ & $9.82 \pm 0.14^{b}$ & $7.89 \pm 0.11^{a b}$ \\
\hline & $220 \mu \mathrm{g} \mathrm{mL}^{-1}$ & $8.86 \pm 0.21^{a b}$ & $11.68 \pm 0.19^{b}$ & $9.17 \pm 0.24^{b}$ \\
\hline & $330 \mu \mathrm{g} \mathrm{mL}^{-1}$ & $10.31 \pm 0.26^{b}$ & $10.54 \pm 0.32^{b}$ & $9.23 \pm 0.18^{b}$ \\
\hline \multirow[t]{5}{*}{ Protease } & $0 \mu \mathrm{g} \mathrm{mL}^{-1}$ & $2.03 \pm 0.04^{a}$ & $2.07 \pm 0.08^{a}$ & $2.06 \pm 0.05^{a}$ \\
\hline & $55 \mu \mathrm{g} \mathrm{mL}^{-1}$ & $2.08 \pm 0.04^{a}$ & $2.10 \pm 0.09^{a}$ & $2.27 \pm 0.06^{a b}$ \\
\hline & $110 \mu \mathrm{g} \mathrm{mL}^{-1}$ & $2.41 \pm 0.06^{a}$ & $3.04 \pm 0.14^{a b}$ & $2.79 \pm 0.08^{a b}$ \\
\hline & $220 \mu \mathrm{g} \mathrm{mL}^{-1}$ & $2.69 \pm 0.05^{a}$ & $4.36 \pm 0.19^{b}$ & $3.73 \pm 0.04^{b}$ \\
\hline & $330 \mu \mathrm{g} \mathrm{mL}^{-1}$ & $2.27 \pm 0.07^{a}$ & $3.14 \pm 0.12^{b}$ & $2.43 \pm 0.10^{a b}$ \\
\hline \multirow[t]{5}{*}{ Lipase } & $0 \mu \mathrm{g} \mathrm{mL}^{-1}$ & $4.83 \pm 0.08^{a}$ & $4.91 \pm 0.06^{a}$ & $5.04 \pm 0.06^{a}$ \\
\hline & $55 \mu \mathrm{g} \mathrm{mL}^{-1}$ & $4.97 \pm 0.06^{a}$ & $5.12 \pm 0.05 a$ & $5.26 \pm 0.08^{a}$ \\
\hline & $110 \mu \mathrm{g} \mathrm{mL}^{-1}$ & $5.29 \pm 0.09^{a b}$ & $5.39 \pm 0.06^{a b}$ & $5.44 \pm 0.05^{a}$ \\
\hline & $220 \mu \mathrm{g} \mathrm{mL}^{-1}$ & $5.41 \pm 0.11^{a b}$ & $6.32 \pm 0.08^{b}$ & $5.36 \pm 0.07^{a}$ \\
\hline & $330 \mu \mathrm{g} \mathrm{mL}^{-1}$ & $6.57 \pm 0.08^{b}$ & $6.28 \pm 0.09^{b}$ & $5.23 \pm 0.08^{a}$ \\
\hline
\end{tabular}

hexadecanoic acid and the lowest percentage peak $(2.91 \%)$ was identified for myristoleic acid at a retention time of $20.93 \mathrm{~min}$. The major abundance of methyl esters of hexadecanoic acid and eicosanoic acid indicated that $\mathrm{C}_{16}$ and $\mathrm{C}_{20}$ were the main fatty acid components of the purified biosurfactant. The results revealed that the biosurfactant was a mixture of 11 different compounds $\left(\mathrm{C}_{6}-\mathrm{C}_{27}\right)$ consisting of long chain $\beta$-hydroxy fatty acid, hexadecanethiol, and heptacosane. Results obtained in this study were consistent with those of Yakimov et al. (1995), wherein lipopeptide surfactant from $B$. licheniformis BAS50 had a mixture of $14 \beta$-hydroxy fatty acids ranging in size from $C_{12}$ to $C_{17}$. The result was also similar to that of another study by Rajeswari et al. (2016), wherein GC-MS data for a biosurfactant from S. hominis showed that it was a mixture of 17 different $\beta$-hydroxy fatty acids $\left(\mathrm{C}_{8}-\mathrm{C}_{27}\right)$.

\section{Modulation of Immune Responses}

The present study demonstrated that B. licheniformis-derived biosurfactant was able to modulate immune responses in L. rohita. Lysozyme has substantial bactericidal activity against both gram-positive and gram-negative bacteria in the presence of complement (Giri et al., 2015). In fish, complement alarms the host immune system to the existence of potential pathogens and assists in their subsequent clearance (Holland and Lambris, 2002). The highest $(P<0.05)$ LA and ACP activities were recorded at 14 days in the S220 group. However, both activities declined slightly at 21 days, when compared to those obtained at 14 days. Similarly, dietary supplementation with $B$. licheniformis SY-52-derived secondary metabolites was previously shown to enhance LA in C. carpio (Chen et al., 2015). Dietary administration of extracellular proteins from Aeromonas veronii BA-1 and Flavobacterium sasangense BA-3 significantly enhanced lysozyme and complement C3 activities in C. carpio (Chi et al., 2014). L. rohita administered cellular components of probiotic bacteria had significantly higher LA and ACP activities (Giri et al., 2015). In addition, phospholipid biosurfactants isolated from $S$. hominis increased the LA in O. mossambicus (Rajeswari et al., 2016).

'PA is an important tool and primordial defense mechanism of the non-specific immune system' (Chen et al., 2015). In the present study, PA was significantly higher in the S220 and S330 groups than in the control group at all time points (Table 4). Earlier studies revealed that bacterial metabolites can increase PA in fish (Chen et al., 2015; Giri et al., 2016c). In the present study, IgM levels were higher in the biosurfactant treated groups (Table 4). Fish in the S220 group exhibited higher $(P<0.05)$ IgM levels at all time points (Table 4). IgM is the predominant antibody type in fish. It is used to identify and neutralize foreign objects such as bacteria and viruses (Giri et al., 2014). Similarly, cellular components of the probiotics Kocuria SM1 and Rhodococcus SM2 increased IgM levels in Oncorhynchus mykiss (Sharifuzzaman et al., 2011). Earlier studies demonstrated that probiotic supplementation increased IgM levels in fish at an initial time point; however, at later time points, these levels declined (Sun et al., 2010; Giri et al., 2013, 2014). In this study, IgM levels increased initially and thereafter they decreased gradually, suggesting that IgM increases is a temporary phenomenon attributable to immunostimulants. Further, LA, PA, ACP, and IgM activities were lower in the S330 group than in the S220 group, suggesting that administration of overdoses of bacterial metabolites could result in the suppression of immune responses in fish (Giri et al., 2016c).

\section{Digestive Enzyme Activities}

Administration (i.p.) of biosurfactant enhanced digestive enzyme activities in fish (Table 5). Amylase, protease, and lipase activities were higher in the treated groups. The digestion processes in aquatic animals can be enhanced 

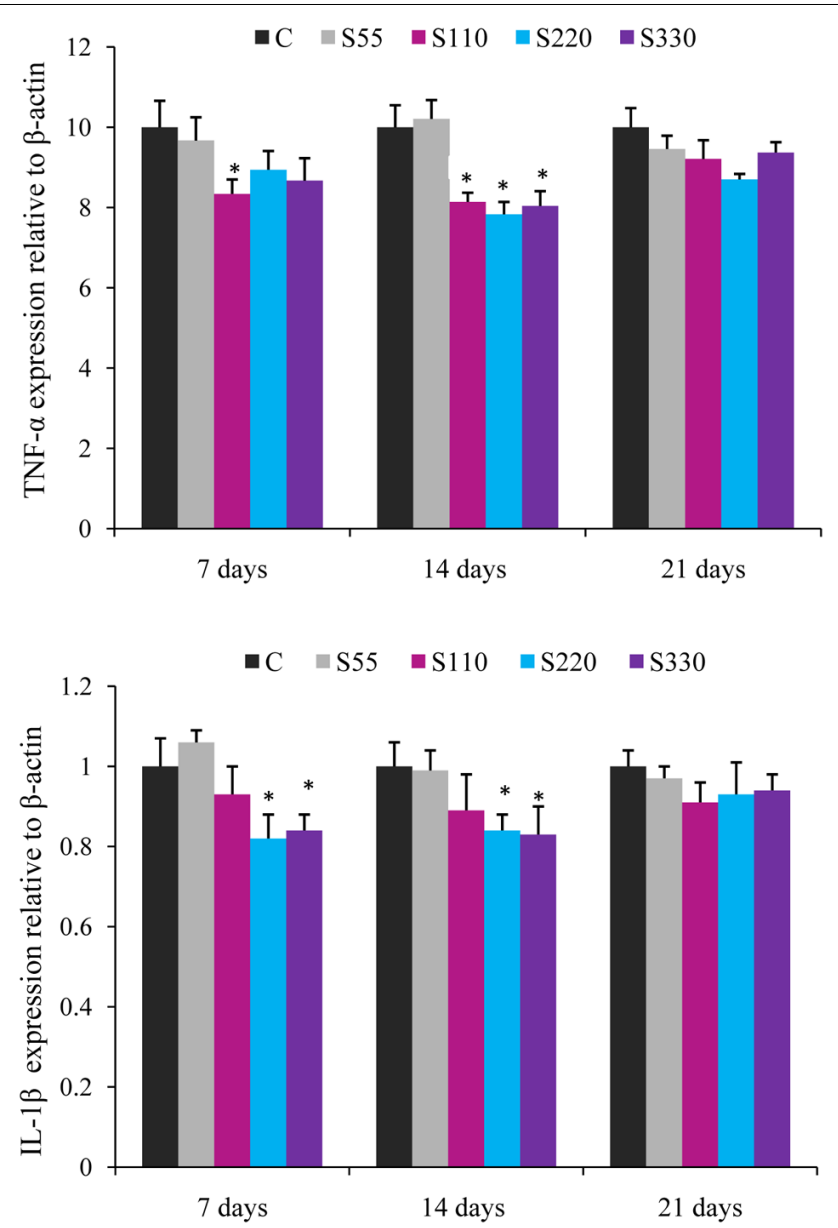

FIGURE 2 | Relative mRNA expression of pro-inflammatory cytokines (TNF- $\alpha$, IL-1 $\beta$ ) in the head-kidney of Labeo rohita administered (i.p.) with biosurfactant. Bars represent the mean $\pm \operatorname{SEM}(n=9)$. A significant difference compared to the control is indicated by an asterisk $(P<0.05)$.

by the addition of certain microorganisms or their byproducts, which can boost the production of extracellular enzymes such as proteases and lipases, and/or can have the intended ability of supplying necessary growth factors as fatty acids and vitamins, among others (Ibrahem, 2015). Earlier studies reported that probiotic bacteria could enhance the secretion of digestive enzymes in fish (Essa et al., 2010; Mohapatra et al., 2012; Sankar et al., 2016). Therefore, increased production of digestive enzymes could improve digestion, which could in turn increase the growth performance of the fish.

\section{Cytokine Gene Expression}

"Cytokines originate from macrophages, lymphocytes, granulocytes, dendritic cells, mast cells, and epithelial cells and include ILs, TNFs, TGFs, IFNs, and chemokines" (Savan and Sakai, 2006). Pro-inflammatory cytokines IL-1 $\beta$ and TNF- $\alpha$ are mainly produced by monocytes and macrophages and regulate numerous aspects of the immune response (Giri et al., 2015).

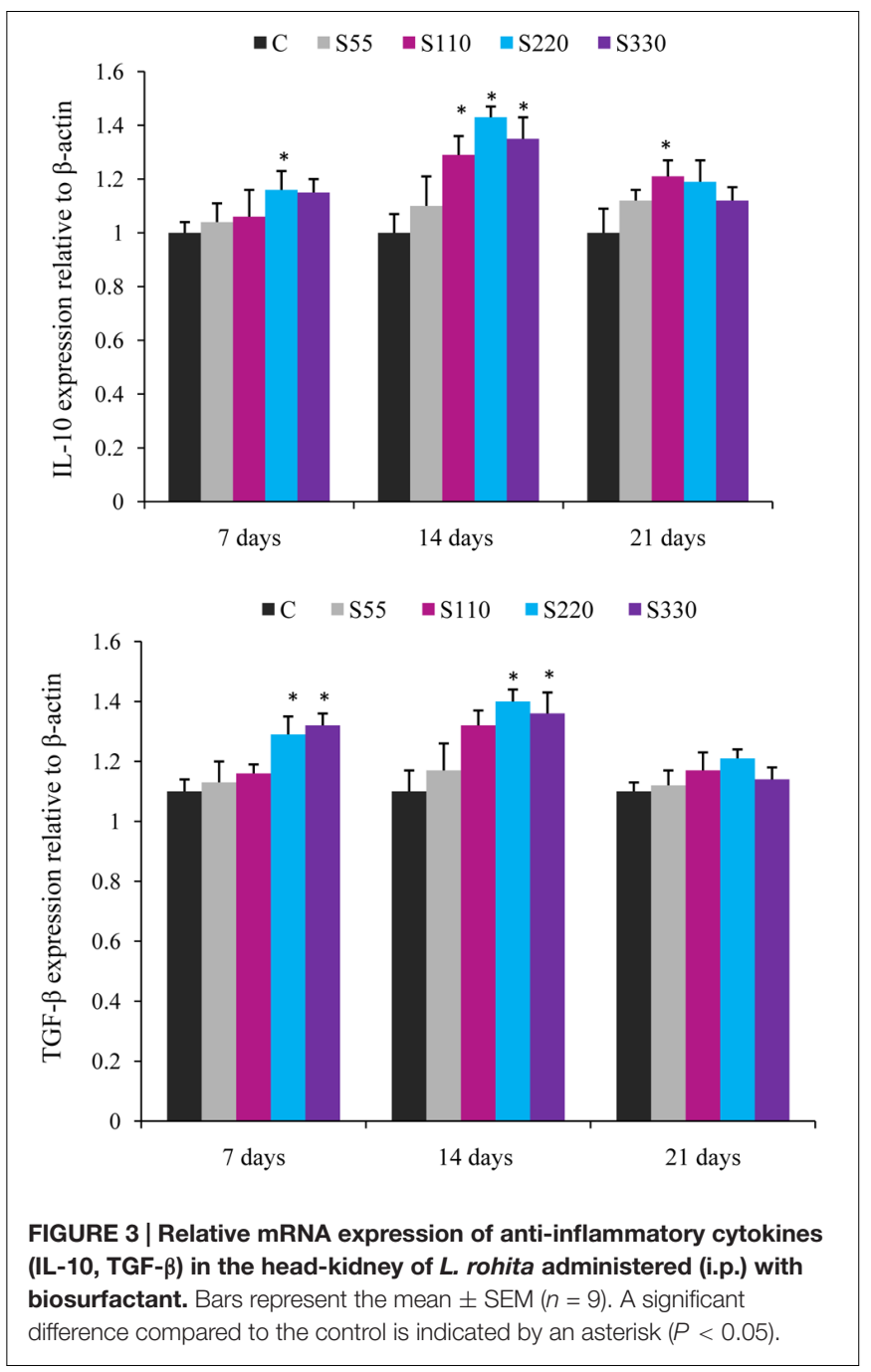

In the present study, administration of biosurfactant (S220 and S330) significantly lowered TNF- $\alpha$ and IL- $\beta$ expression in the head-kidney of fish at $14 \mathrm{dpa}$ (Figure 1). In a similar study, we previously showed that administration of biosurfactant could down-regulate the expression of TNF- $\alpha$ and IL-1 $\beta$ in L. rohita (Giri et al., 2016c). However, biosurfactant (S110-S330) significantly upregulated the expression of anti-inflammatory cytokines (IL-10 and TGF- $\beta$ ) at $14 \mathrm{dpa}$, and maximum expression was recorded in the S220 group (Figure 2). This is consistent with increased IL-10 and TGF- $\beta$ expression observed in L. rohita immunized with biosurfactant (Giri et al., 2016c). In addition, IL-10 expression was up-regulated in rainbow trout cell cultures stimulated with lipopolysaccharide (Fierro-Castro et al., 2013) and in C. carpio administered bacterial secondary metabolites (Chen et al., 2015). The observed inverse relationships between the expression of pro- and anti-inflammatory cytokines in the present study is consistent with earlier studies wherein fish were administrated immunostimulants (Feng et al., 2016; Giri et al., 2016c). IL-10 is produced mainly by monocytes, macrophages, B cells, T cells, and dendritic cells. It inhibits the expression of many pro-inflammatory cytokines (De Waal Malefyt et al., 1991). 


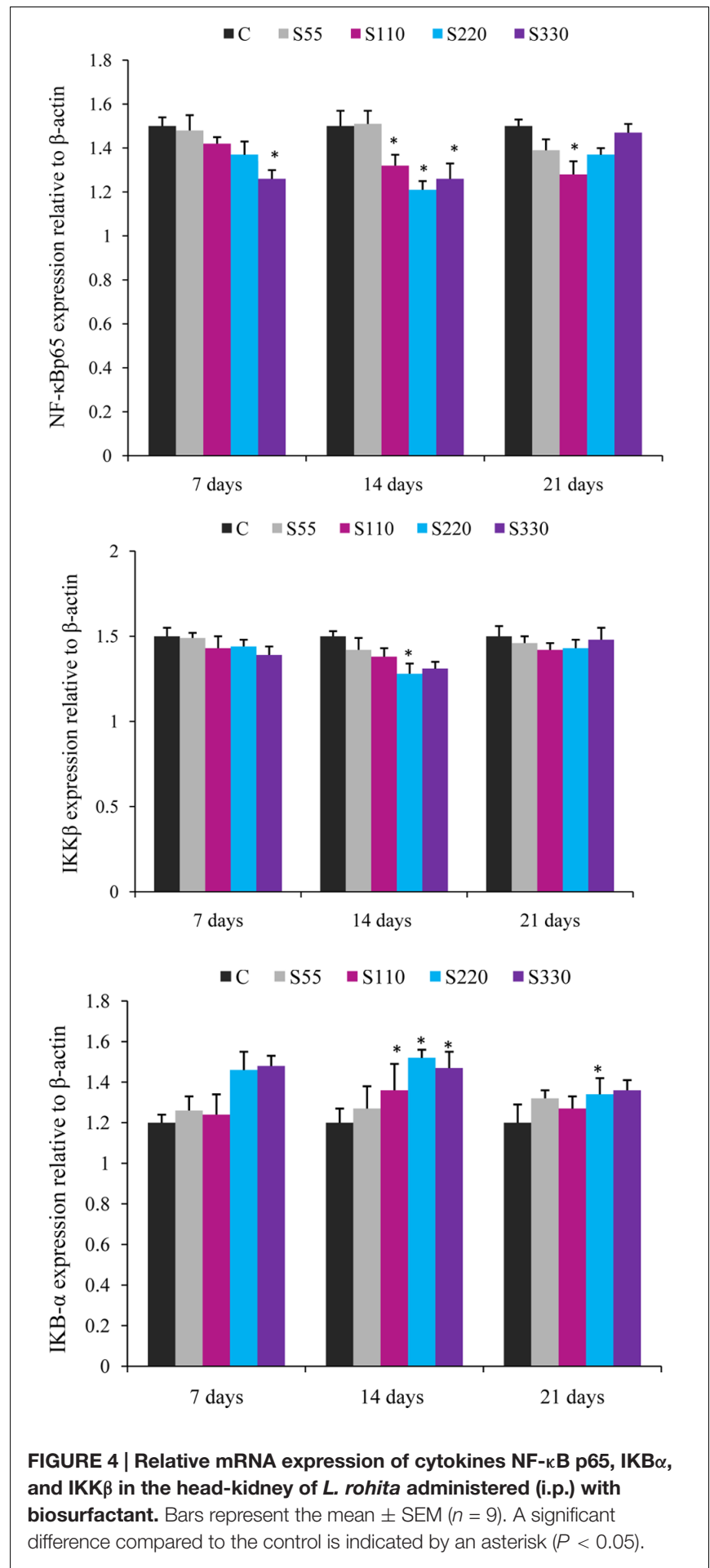

“TGF- $\beta$ inhibits B and T cell proliferation and differentiation, antagonizes pro-inflammatory cytokines such as IL-1 $\beta$, TNF$\alpha$, and IFN- $\gamma$, and blocks the expression of IL-1 $\beta$ and IL-2 receptors" (Li and Flavell, 2008). These results suggest that the administration of $220 \mu \mathrm{g} \mathrm{mL}-1$ of biosurfactant attenuates pro-inflammatory responses in fish.
TABLE 6A | Inhibition of biofilm formation by biosurfactant.

\begin{tabular}{lccc}
\hline $\begin{array}{l}\text { Sample } \\
\text { number }\end{array}$ & $\begin{array}{c}\text { Biofilm formation } \\
\text { (OD) at } \mathbf{6 6 0} \mathbf{~ n m}\end{array}$ & $\begin{array}{c}\text { Biofilm inhibition } \\
\text { by biosurfactant } \\
\text { (OD) at } \mathbf{6 6 0} \mathbf{~ n m}\end{array}$ & $\begin{array}{c}\text { \% inhibition of } \\
\text { biofilm }\end{array}$ \\
\hline 1 & 0.316 & 0.183 & $41.38 \pm 1.09$ \\
2 & 0.239 & 0.152 & $36.62 \pm 1.13$ \\
3 & 0.388 & 0.173 & $54.71 \pm 1.27$ \\
4 & 0.281 & 0.147 & $47.68 \pm 0.54$ \\
5 & 0.226 & 0.139 & $38.49 \pm 0.68 \mathrm{~s}$ \\
\hline
\end{tabular}

TABLE 6B | Initial and final concentrations of cadmium (Cd) in treated vegetables and its removal percent after treatment with biosurfactant.

\begin{tabular}{lcccc}
\hline $\begin{array}{c}\text { SI. } \\
\text { No. }\end{array}$ & $\begin{array}{c}\text { Name of } \\
\text { the } \\
\text { vegetable }\end{array}$ & $\begin{array}{c}\text { Initial } \\
\text { concentration } \\
\text { of cadmium }\end{array}$ & $\begin{array}{c}\text { Final } \\
\text { concentration } \\
\text { of cadmium }\end{array}$ & \% Cd removal \\
\hline 1 & Carrot & 0.5721 & 0.3427 & $41.16 \pm 1.73$ \\
2 & Radish & 0.5038 & 0.2396 & $52.83 \pm 1.86$ \\
3 & Ginger & 0.3317 & 0.1294 & $60.98 \pm 1.29$ \\
4 & Potato & 0.4193 & 0.2416 & $42.68 \pm 0.74$ \\
\hline
\end{tabular}

$\mathrm{NF}-\kappa \mathrm{B}$, a critical transcription factor that is involved in the inflammatory response, controls the expression of various compounds such as IL-6, IL- $1 \beta$, TNF- $\alpha$, iNOS, and COX-2 (Cho et al., 2013). In this study, mRNA expression of NF- $\kappa$ B p65 significantly declined during the entire duration of the trial (Figure 3) and the lowest expression was recorded in the S220

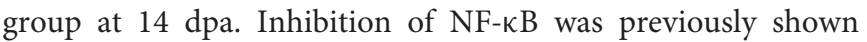
to down-regulate the expression of IL- $1 \beta$ and IL- 8 in mouse monocytes ( $\mathrm{Li}$ et al., 2008). Further, IкB- $\alpha$ expression was higher in the biosurfactant-treated groups (Figure 3). However, IKK$\beta$ mRNA was lower in the treated groups and this difference was significantly lower only in the S220 group at 14 dpa (Figure 3). Up-regulation of I $\kappa \mathrm{B}-\alpha$, an NF- $\kappa \mathrm{B}$ binding protein, was shown to lead to down-regulation of pro-inflammatory cytokines in mouse muscle fibers (Hnia et al., 2008). Further, IL10 can attenuate pro-inflammatory cytokine production through the suppression of NF- $\kappa \mathrm{B}$ activation by sustaining I $\mathrm{B}$ protein expression (Chon et al., 2010). Therefore, our results indicated that biosurfactant might act by down-regulating the expression of IKK- $\beta$ to attenuate the degradation of I $\kappa$ B- $\alpha$, thereby inhibiting NF- $\kappa$ B p65 nuclear translocation, to suppress the expression of pro-inflammatory cytokines (Giri et al., 2016c). However, the underlying mechanism requires further investigation.

\section{Challenge Study}

In the present study, carp treated with (i.p.) biosurfactant showed increased protection against $A$. hydrophila. Fish administered $220 \mu \mathrm{g} \mathrm{mL} \mathrm{m}^{-1}$ of biosurfactant (S220) exhibited the highest RPS (72.72\%). In a recent study, we demonstrated that L. rohita treated with (i.p.) with $200 \mu \mathrm{g} \mathrm{mL} \mathrm{m}^{-1}$ of B. subtilisderived biosurfactant were most protected against $A$. hydrophila infection (Giri et al., 2016c). Dietary administration of secondary metabolites isolated from B. licheniformis XY-52 enhanced the survival of $C$. carpio against $A$. hydrophila challenge (Chen et al., 2015). O. mossambicus administered S. hominis-derived 
phospholipid biosurfactant (200 $\mathrm{mg} \mathrm{kg}^{-1}$ ) were most protected against $A$. hydrophila challenge (Rajeswari et al., 2016). The improved immune parameters (LA, ACP, PA, and IgM) and digestive enzyme activities, and higher expression of antiinflammatory cytokines in fish treated with $220 \mu \mathrm{g} \mathrm{mL} \mathrm{m}^{-1}$ of biosurfactant might be linked with the enhanced resistance to A. hydrophila, which could result in higher post-challenge survival. The groups injected with 55,110 , or $330 \mu \mathrm{g} \mathrm{mL}-1$ of biosurfactant exhibited lower post-challenge survival, which might be associated with the obtained results regarding immune responses, digestive enzyme activities, and immune gene expression. These results indicate that B. licheniformis VS16derived biosurfactant has immunomodulatory effects on carp.

\section{Biofilm Inhibition and Heavy Metal Removal by Biosurfactant}

The biosurfactant was effective in suppressing biofilm formation (Table 6A) by up to 54\%. Controlling the adherence of microorganisms to the food contact surface is critical for providing safe and healthy food products to consumers (Anjum et al., 2016). Therefore, the use of biosurfactants in inhibiting biofilm formation could be an important tool for the food industry. Glycolipid biosurfactant (30 $\mu \mathrm{g}$ glycolipid $\mathrm{mL}^{-1}$ ) derived from Brevibacterium casei was shown to significantly inhibit biofilm production by Vibrio spp., E. coli, and Pseudomonas spp. of both mixed culture and individual strains (Kiran et al., 2010a). Nocardiopsis sp. MSA13Aderived biosurfactant $\left(300 \mu \mathrm{g} \mathrm{mL} \mathrm{m}^{-1}\right)$ significantly disrupted biofilm formation in Vibrio alginolyticus (Kiran et al., 2014). Biosurfactant isolated from Lysinibacillus fusiformis S9 exhibited notable inhibition of biofilm formation by pathogenic E. coli or Streptococcus mutans (Pradhan et al., 2014). They reported that at a concentration of $40 \mu \mathrm{g} \mathrm{mL}^{-1}$ the biosurfactant efficiently inhibited biofilm formation by E. coli and S. mutans. Further, Falagas and Makris (2009) hypothesized that 'probiotics or their products (biosurfactants) could be applied to patient care equipment such as tubes or catheters with the aim of decreasing colonization by nosocomial pathogens.'

The intake of heavy metals though food or any other means is highly detrimental to human health. The uptake of heavy metals by crops is often associated with the plant species, growth phase, soil type, metal variety, soil conditions, environment, and weather. We found that biosurfactant has the potential to remove cadmium from carrots, radishes, ginger, and potatoes (Table 6B). Recently, Anjum et al. (2016) demonstrated that Bacillus sp. METCC 5877-derived biosurfactant removes considerable amounts of heavy metals from vegetables such as potatoes, garlic, radishes, and onions. In addition, rhamnolipids (glycolipids)

\section{REFERENCES}

Amend, D. F. (1981). Potency testing of fish vaccines. Dev. Biol. Stand. 49, 447-454.

American Public Health Association [APHA], American Water Works Association [AWWA], Water Environment Federation [WEF] (2012). Standard Methods removed nickel and cadmium from soils with efficiencies of 80$100 \%$, when tested in a controlled environment, and this removal efficiency was 20-80\%, when using field samples (Wang and Mullingan, 2004). Therefore, the controlled and cautious use of these exciting surface active molecules will definitely assist in the removal of the toxic environmental pollutants and could help provide a clean environment.

\section{CONCLUSION}

Injection (i.p.) of $L$. rohita with $220 \mu \mathrm{g} \mathrm{mL}-1$ biosurfactant derived from $B$. licheniformis VS16 boosted immune responses, leading to improved functional immunity in terms of disease resistance against live virulent $A$. hydrophila. Furthermore, biosurfactant administration modulated cytokine-related gene expression in the head kidney of fish. Biosurfactants are biocompatible and biodegradable, and were shown to effectively inhibit biofilm formation and efficiently remove heavy metals from tested vegetables. Therefore, purified biosurfactant from B. licheniformis VS16 could have applications in aquaculture as an immunostimulant to prevent diseases, as well as in food processing for the removal of heavy metals from vegetables and to control biofilm formation.

\section{AUTHOR CONTRIBUTIONS}

Designed the experiments: SG, VS. Conceived and supervised the study: SS, VS, SP. Performed the experiments: SG, SS, VS. Data analyzed by: SG, JJ. Wrote the manuscript: SG, SS. Proofread the manuscript: SP.

\section{FUNDING}

Authors gratefully acknowledge the research grant received from the National Research Foundation of Korea, Ministry of Education (NRF-2014R1A2A1A11050093).

\section{ACKNOWLEDGMENTS}

This work was supported by 'Korea Research Fellowship Program' through the National Research Foundation of Korea (NRF) funded by the Ministry of Science, ICT and Future Planning (2016H1D3A1909005). SS is a recipient of D.S. Kothari Post-Doctoral Fellowship (No. F4-2/2006(BSR)/ME/14-15/0002) from University Grant Commission, GoI.

for the Examination of Water and Wastewater, 22nd Edn. Washington, DC: American Public Health Association.

Anandaraj, B., and Thivakaran, P. (2010). Isolation and production of biosurfactant producing organism from oil spilled soil. J. Biosci. Tech. 1, 120-126.

Anjum, F., Gautam, G., Edgard, G., and Negi, S. (2016). Biosurfactant production through Bacillus sp. MTCC 5877 and its multifarious applications in food 
industry. Bioresour. Bioprocess. 213, 262-269. doi: 10.1016/j.biortech.2016. 02.091

Anson, M. L. (1938). The estimation of pepsin, trypsin, papain, and cathepsin with hemoglobin. J. Gen. Physiol. 1938, 79-89. doi: 10.1085/jgp.22.1.79

Austin, B., and Austin, D. A. (2007). Bacterial Fish Pathogens: Diseases of Farmed and Wild Fish, 4th Edn. Chichester: Springer.

Bezza, F. A., and Chirwa, E. M. N. (2015). Production and applications of lipopeptide biosurfactant for bioremediation and oil recovery by Bacillus subtilis CN2. Biochem. Eng. J. 101, 168-178. doi: 10.1016/j.bej.2015.05.007

Bodour, A. A., Guerrero-Barajas, C., Jiorle, B. V., Malcomson, M. E., Bates, R. B., and Maier, R. M. (2004). Structure and characterization of flavolipids, a novel group of biosurfactants produced by Flavobacterium sp. strain MTN11. Appl. Environ. Microbiol. 70, 114-120. doi: 10.1128/AEM.70.1.114120.2004

Busscher, H. J., van der Kuij-Booij, M., and van der Mei, H. C. (1996). Biosurfactants from thermophilic dairy streptococci and their potential role in the fouling control of heat exchanger plates. J. Ind. Microbiol. 16, 15-21. doi: 10.1007/BF01569916

Chandrasekharan, E. V., and Bemiller, J. N. (1980). Methods in Carbohydrate Chemistry. New York, NY: Academic Press.

Chen, X.-M., Lu, M. H., Niu, X. T., Wang, G. Q., and Zhang, D. M. (2015). Enhancement of secondary metabolites from Bacillus licheniformis XY-52 on immune response and expression of some immune-related genes in common carp, Cyprinus carpio. Fish Shellish Immunol. 45, 124-131. doi: 10.1016/j.fsi.2015.02.019

Chi, C., Jiang, B., Yu, X.-B., Liu, T.-Q., Xia, L., and Wang, G.-X. (2014). Effects of three strains of intestinal autochthonous bacteria and their extracellular products on the immune response and disease resistance of common carp, Cyprinus carpio. Fish Shellfish Immunol. 36, 9-18. doi: 10.1016/j.fsi.2013.10.003

Cho, H. J., Lee, K. W., and Park, J. H. Y. (2013). Erucin exerts anti-inflammatory properties in murine macrophages and mouse skin: possible mediation through the inhibition of NFKB signalling. Int. J. Mol. Sci. 14, 20564-20577. doi: 10.3390/ ijms141020564

Chon, H., Choi, B., Jeong, G., Lee, E., and Lee, S. (2010). Suppression of proinflammatory cytokine production by specific metabolites of Lactobacillus plantarum 10hk2 via inhibiting NF- $\mathrm{BB}$ and $\mathrm{p} 38$ MAPK expressions. Comp. Immunol. Microbiol. Infect. Dis. 33, 41-49. doi: 10.1016/j.cimid.2009.11.002

Dagbert, C., Meylheuc, T., and Bellon-Fontaine, M. N. (2006). Corrosion behavior of AISI 304 stainless steel in presence of a biosurfactant produced by Pseudomonas fluorescens. Electrochim. Acta 51, 5221-5227. doi: 10.1016/j. electacta.2006.03.063

Das, K., and Mukherjee, A. K. (2007). Comparison of lipopeptide biosurfactants production by Bacillus subtilis strains in submerged and solid state fermentation systems using a cheap carbon source: some industrial applications of biosurfactants. Process Biochem. 42, 1191-1199. doi: 10.1016/j.procbio.2007. 05.011

De Waal Malefyt, R., Abrams, J., Bennett, B., Figdor, C. G., and De Vries, J. E. (1991). Interleukin 10 (IL-10) inhibits cytokine synthesis by human monocytes: an autoregulatory role of IL-10 produced by monocytes. J. Exp. Med. 174, 1209-1220. doi: 10.1084/jem.174.5.1209

Deepak, R., and Jayapradha, R. (2015). Lipopeptide biosurfactant from Bacillus thuringiensis pak2310: a potential antagonistic against Fusarium oxysporum. J. Mycol. Med. 25, 15-24. doi: 10.1016/j.mycmed.2014.10.011

Donio, M. B. S., Ronica, S. F. A., Thanga Viji, V., Velmurugan, S., Adlin Jenifer, J., Michaelbabu, M., et al. (2013). Isolation and characterization of halophilic Bacillus sp. BS3 able to produce pharmacologically important biosurfactants. Asian Pac. J. Trop. Med. 6, 876-883. doi: 10.1016/S1995-7645(13) 60156-X

Ellis, A. E. (1990). "Lysozyme assay," in Techniques in Fish Immunology, eds J. S. Stolen, T. C. Fletcher, D. P. Anderson, B. S. Robertson, and W. B. Van Muiswinkel (Fair Haven, NJ: SOS Publications), 101-103.

Essa, M. A., El-Serafy, S. S., El-Ezabi, M. M., Daboor, S. M., Esmael, N. A., and Lall, S. P. (2010). Effect of different dietary probiotics on growth, feed utilization and digestive enzymes activities of Nile tilapia, Oreochromis niloticus. J. Arab. Aquacult. Soc. 5, 143-162.

Falagas, M. E., and Makris, G. C. (2009). Probiotic bacteria and biosurfactants for nosocomial infection control: a hypothesis. J. Hosp. Infect. 71, 301-306. doi: 10.1016/j.jhin.2008.12.008
FAO (2014). The State of World Fisheries and Aquaculture. Rome: Food and Agriculture Organization of the United Nations.

Feigner, C., Besson, F., and Michel, G. (1995). Studies on lipopeptide biosynthesis by Bacillus subtilis: isolation and characterization of iturin, surfactin mutants. FEMS Microbiol. Lett 127, 11-15. doi: 10.1016/0378-1097(95) 00028-4

Feng, L., Chen, Y.-P., Jiang, W.-D., Liu, Y., Jiang, J., Wu, P., et al. (2016). Modulation of immune response, physical barrier and related signaling factors in the gills of juvenile grass carp (Ctenopharyngodon idella) fed supplemented diet with phospholipids. Fish Shellfish Immunol. 48, 79-93. doi: 10.1016/j.fsi. 2015.11.020

Fierro-Castro, C., Barrioluengo, L., López-Fierro, P., Razquin, B. E., and Villena, A. J. (2013). Fish cell cultures as in vitro models of inflammatory responses elicited by immunostimulants. Expression of regulatory genes of the innate immune response. Fish Shellfish Immunol. 35, 979-987. doi: 10.1016/j.fsi.2013. 07.015

Finney, D. J. (1980). Probit Analysis, 3rd Edn. Cambridge: Cambridge University Press.

Furné, M., Hidalgo, M. C., López, A., García-Gallego, M., Morales, A. E., Domezain, A., et al. (2005). Digestive enzyme activities in adriatic sturgeon Acipenser naccarii and rainbow trout Oncorhynchus mykiss- A comparative study. Aquaculture 250, 391-398. doi: 10.1016/j.aquaculture.2005.05.017

Geng, X., Dong, X. H., Tan, B. P., Yang, Q. H., Chi, S. Y., Liu, H. Y., et al. (2012). Effects of dietary probiotic on the growth performance, non-specific immunity and disease resistance of cobia, Rachycentron canadum. Aquacult. Nutr. 18, 46-55. doi: 10.1016/j.fsi.2011.06.006

Giri, S. S., Chi, C., Jun, J. W., and Park, S. C. (2016a). Use of bacterial subcellular components as immunostimulants in fish aquaculture. Rev. Aquacult. doi: 10. $1111 /$ raq. 12182

Giri, S. S., Jun, J. W., Sukumaran, V., and Park, S. C. (2016b). Dietary administration of banana (Musa acuminata) peel flour affects the growth, antioxidant status, cytokine responses, and disease susceptibility of rohu, Labeo rohita. J. Immunol. Res. 2016:4086591. doi: 10.1155/2016/4086591

Giri, S. S., Sen, S. S., Chi, C., Kim, H. J., Yun, S., Park, S. C., et al. (2015). Effect of cellular products of potential probiotic bacteria on the immune response of Labeo rohita and susceptibility to Aeromonas hydrophila infection. Fish Shellfish Immunol. 46, 716-722. doi: 10.1016/j.fsi.2015.08.012

Giri, S. S., Sen, S. S., Jun, J. W., Sukumaran, V., and Park, S. C. (2016c). Role of Bacillus subtilis VSG4-derived biosurfactant in mediating immune responses in Labeo rohita. Fish Shellfish Immunol. 54, 220-229. doi: 10.1016/j.fsi.2016. 04.004

Giri, S. S., Sukumaran, V., and Oviya, M. (2013). Potential probiotic Lactobacillus plantarum VSG3 improves the growth, immunity, and disease resistance of tropical freshwater fish, Labeo rohita. Fish Shellfish Immunol. 34, 660-666. doi: $10.1016 /$ j.fsi.2012.12.008

Giri, S. S., Sukumaran, V., Sen, S. S., and Jena, P. K. (2014). Effects of dietary supplementation of potential probiotic Bacillus subtilis VSG1 singularly or in combination with Lactobacillus plantarum VSG3 or/and Pseudomonas aeruginosa VSG2 on the growth, immunity and disease resistance of Labeo rohita. Aquacult. Nutr. 20, 163-171. doi: 10.1111/anu.12062

Hnia, K., Gayraud, J., Hugon, G., Ramonatxo, M., De La Porte, S., Matecki, S., et al. (2008). L-arginine decreases inflammation and modulates the nuclear factor$\mathrm{kB} /$ matrix metalloproteinase cascade in $\mathrm{mdx}$ muscle fibers. Am. J. Pathol. 172, 1509-1519. doi: 10.2353/ajpath.2008.071009

Holland, M. C. H., and Lambris, J. D. (2002). The complement system in teleosts. Fish Shellfish Immunol. 12, 399-420. doi: 10.1006/fsim.2001.0408

Holt, J. G., Krieg, N. R., Sneath, P. H. A., Staley, J. T., and Williams, S. T. (1994). Bergey's Manual of Determinative Bacteriology, 9th Edn. Balitomore, MD: Williamsons and Wilkins.

Ibrahem, M. D. (2015). Evolution of probiotics in aquatic world: potential effects, the current status in Egypt and recent prospectives. J. Adv. Res. 6, 765-791. doi: 10.1016/j.jare.2013.12.004

Iyer, A., Mody, K., and Jha, B. (2006). Emulsifying properties of a marine bacterial exopolysaccharide. Enzyme Microbial Technol. 38, 220-222. doi: 10.1016/j. enzmictec.2005.06.007

Joshi, S. J., Geetha, S. J., Yadav, S., and Desai, A. J. (2013). Optimization of benchscale production of biosurfactant by Bacillus licheniformis R2. APCBEE Procedia 5, 232-236. doi: 10.1016/j.apcbee.2013.05.040 
Kiran, G. S., Nishanth, L. A., Priyadharshini, S., Anitha, K., and Selvin, J. (2014). Effect of Fe nanoparticle on growth and glycolipid biosurfactant production under solid state culture by marine Nocardiopsis sp. MSA13A. BMC Biotechnol. 14:48. doi: 10.1186/1472-6750-14-48

Kiran, G. S., Sabarathnam, B., and Selvin, J. (2010a). Biofilm disruption potential of a glycolipid biosurfactant from marine Brevibacterium casei. FEMS Immunol. Med. Microbiol. 59, 432-438. doi: 10.1111/j.1574-695X.2010.00698.x

Kiran, G. S., Thomas, T. A., Selvin, J., Sabarathnam, B., and Lipton, A. P. (2010b). Optimization and characterization of a new lipopeptide biosurfactant produced by marine Brevibacterium aureum MSA13 in solid state culture. Biores. Technol. 101, 2389-2396. doi: 10.1016/j.biortech.2009.11.023

Li, M. O., and Flavell, R. A. (2008). Contextual regulation of inflammation: a duet by transforming growth factor- $\beta$ and interleukin-10. Immunity 28, 468-476. doi: 10.1016/j.immuni.2008.03.003

Li, Q., Ai, Q., Mai, K., Xu, W., and Zheng, Y. (2013). A comparative study: in vitro effects of EPA and DHA on immune functions of head-kidney macrophages isolated from large yellow croaker (Larmichthys crocea). Fish Shellfish Immunol. 35, 933-940. doi: 10.1016/j.fsi.2013.07.004

Li, Z., Zhang, D. K., Yi, W. Q., Ouyang, Q., Chen, Y. Q., and Gan, H. T. (2008). NF- $\kappa$ B p65 antisense oligonucleotides may serve as a novel molecular approach for the treatment of patients with ulcerative colitis. Arch. Med. Res. 39, 729-734. doi: 10.1016/j.arcmed.2008.08.001

Liu, J., Lei, Y., Wang, F., Yi, Y., Liu, Y., and Wang, G. (2011). Immunostimulatory activities of specific bacterial secondary metabolite of Anoxybacillus flavithermus strain SX-4 on carp, Cyprinus carpio. J. Appl. Microbiol. 110, 1056-1064. doi: 10.1111/j.1365-2672.2011.04963.x

Livak, K. J., and Schmittgen, T. D. (2001). Analysis of relative gene expression data using real-time quantitative PCR and the $2^{-\Delta \Delta C T}$ method. Methods 25 , 402-408. doi: 10.1006/meth.2001.1262

Lowry, O. H., Rosebbrough, N. J., Farr, A. L., and Randall, R. L. (1951). Protein measurement with the folin phenol reagent. J. Biol. Chem. 193, 265-273.

Mckellar, R. C., and Cholette, H. (1986). Determination of the extracellular lipases of Pseudomonas fluorescens spp. in skim milk with the $\beta$-naphthyl caprylate assay. J. Dairy Res. 53, 301-312. doi: 10.1017/S0022029900024900

Misik, J., Vodakova, E., Pavlikova, R., Caba, J., Novotny, L., and Kuca, K. (2012). Acute toxicity of surfactants and detergent-based decontaminants in mice and rats, Mil. Med. Sci. Lett. 81, 171-176.

Mohapatra, S., Chakraborty, T., Prusty, A. K., Das, P., Paniprasad, K., and Mohanta, K. N. (2012). Use of different microbial probiotics in the diet of rohu, Labeo rohita fingerlings: effects on growth, nutrient digestibility and retention, digestive enzyme activities and intestinal microflora. Aquacult. Nutr. 18, 1-11. doi: 10.1111/j.1365-2095.2011.00866.x

Mukherjee, A. K., and Das, K. (2005). Correlation between diverse cyclic lipopeptides production and regulation of growth and substrate utilization by Bacillus subtilis strains in a particular habitat. FEMS Microbiol. Ecol. 54, 479-489. doi: 10.1016/j.femsec.2005.06.003

Nitschke, M., and Costa, S. G. V. A. O. (2007). Biosurfactants in food industry. Trends Food Sci. Technol. 18, 252-259. doi: 10.1016/j.tifs.2007.01.002

Okpokwasili, G. C., and Ibiene, A. A. (2006). Enhancement of recovery of residual oil using a biosurfactant slug. Afr. J. Biotechnol. 5, 453-456.

Omudu, O. S., Ntwampe, S. K. O., and Ojumu, T. V. (2014). Optimization of biosurfactant production by Bacillus licheniformis STK 01 grown exclusively on Beta vulgaris waste using response surface technology. BioResources 9, 5045-5065.

Oviya, M., Giri, S. S., Sukumaran, V., and Natarajan, P. (2012). Immobilization of carbonic anhydrase enzyme purified from Bacillus subtilis VSG-4 and its application as CO2 sequesterer. Prep. Biochem. Biotechnol. 42, 462-475. doi: 10.1080/10826068.2012.654571

Pasnik, D. J., Evans, J. J., Panangala, V. S., Klesius, P. H., Shelby, R. A., and Shoemaker, C. A. (2005). Antigenicity of Streptococcus agalactiae extracellular products and vaccine efficacy. J. Fish Dis. 28, 205-212. doi: 10.1111/j.1365-2761. 2005.00619.x

Perfumo, A., Ranchic, I., and Banat, I. M. (2010). "Biosurfactants," in Biosurfactants Book series: Advances in Experimental Medicine and Biology, ed. R. Sen (Austin, TX: Landes Bioscience), 134-145.

Pradhan, A. K., Pradhan, N., Sukla, L. B., Panda, P. K., and Mishra, B. K. (2014). Inhibition of pathogenic bacterial biofilm by biosurfactant produced by Lysinibacillus fusiformis S9. Bioprocess Biosyst. Eng. 37, 139-149. doi: 10.1007/ s00449-013-0976-5
Rajeswari, V., Priyadarshini, S. K., Saranya, V., Suguna, P., and Shenbagarathai, R. (2016). Immunostimulation by phospholipopeptide biosurfactant from Staphylococcus hominis in Oreochromis mossambicus. Fish Shellfish Immunol. 48, 244-253. doi: 10.1016/j.fsi.2015.11.006

Rodrigues, L. R., Teixeira, J. A., Mei, H. C., and Oliveira, H. (2006). Physicochemical and functional characterization of a biosurfactant produced by Lactococcus lactis 53. Colloid Surf. B Biointerfaces. 49, 79-86. doi: 10.1016/j. colsurfb.2006.03.003

Sankar, H., Philip, B., Philip, R., and Singh, I. S. B. (2016). Effect of probiotics on digestive enzyme activities and growth of cichlids, Etroplus suratensis (Pearl spot) and Oreochromis mossambicus (Tilapia). Aquacult. Nutr. doi: 10.1111/ anu. 12452

Satpure, S. K., Banat, I. M., Dhakephalkar, P. K., Banpurkar, A. G., and Chopade, B. A. (2010). Biosurfactants, bioemulsifiers and exopolysaccharies from marine microorganisms. Biotechnol. Adv. 28, 436-450. doi: 10.1016/j.biotechadv.2010. 02.006

Savan, R., and Sakai, M. (2006). Genomics of fish cytokines. Comp. Biochem. Physiol. Part D Genomics Proteomics 1, 89-101. doi: 10.1016/j.cbd.2005. 08.005

Sharifuzzaman, S. M., Abbas, A., Tinsley, J. W., and Austin, B. (2011). Subcellular components of probiotics Kocuria SM1 and Rhodococcus SM2 induce protective immunity in rainbow trout (Oncorhynchus mykiss, Walbaum) against Vibrio anguillarum. Fish Shellfish Immunol. 30, 347-353. doi: 10.1016/j.fsi.2010.11.005

Siegmund, I., and Wagner, F. (1991). New method for detecting rhamnolipids excreted by Pseudomonas spp during growth on mineral agar. Biotechnol. Tech. 5, 265-268. doi: 10.1007/BF02438660

Sun, Y.-Z., Yang, H.-L., Ma, R.-L., and Lin, W.-Y. (2010). Probiotic applications of two dominant gut Bacillus strains with antagonistic activity improved the growth performance and immune responses of grouper Epinephelus coioides. Fish Shellfish Immunol. 29, 803-809. doi: 10.1016/j.fsi.2010.07.018

Swaathy, S., Kavitha, V., Pravin, A. S., Mandal, A. B., and Gnanamani, A. (2014). Microbial surfactant mediated degradation of anthracene in aqueous phase by marine Bacillus licheniformis MTCC 5514. Biotechnol. Rep. 4, 161-170. doi: 10.1016/j.btre.2014.10.004

Uribe, C., Folch, H., Enriquez, R., and Moran, G. (2011). Innate and adaptive immunity in teleost fish: a review. Vet. Med. 56, 486-503.

Wang, G.-X., Wang, Y., Wu, Z.-F., Jiang, H.-F., Dong, R.-Q., Li, F.-Y., et al. (2011). Immunomodulatory effects of secondary metabolites from thermophilic Anoxybacillus kamchatkensis XA-1 on carp, Cyprinus carpio. Fish Shellfish Immunol. 30, 1331-1338. doi: 10.1016/j.fsi.2011.03.011

Wang, S., and Mullingan, C. N. (2004). Rhamnolipid foam enhanced remediation of cadmium and nickel contaminated soil. Water Air Soil Pollut. 157, 315-330. doi: 10.1023/B:WATE.0000038904.91977.f0

Welker, T. L., Lim, C., Yildirim-Aksoy, M., and Klesius, P. H. (2007). Growth, immune function, and disease and stress resistance of juvenile Nile tilapia (Oreochromis niloticus) fed graded levels of bovine lactoferrin. Aquaculture 262, 156-162. doi: 10.1016/j.aquaculture.2006.09.036

Yakimov, M. M., Timmis, K. N., Wray, V., and Fredrickson, H. L. (1995). Characterization of a new lipopeptide surfactant produced by thermotolerant and halotolerant subsurface Bacillus licheniformis BAS50. Appl. Environ. Microbiol 61, 1706-1713.

Yano, T. (1992). "Assays of hemolytic complement activity," in Techniques in Fish Immunology, eds J. S. Stolen, T. C. Fletcher, D. P. Anderson, S. L. Kaattari, and A. F. Rowley (Fair Haven, NJ: SOS Publications), 131-141.

Zouari, R., Ellouze-Chaabouni, S., and Ghribi-Aydi, D. (2014). Optimization of Bacillus subtilis SPB1 biosurfactant production under solid-state fermentation using by-products of a traditional olive mill factory. Ach. Life Sci. 8, 162-169. doi: 10.1016/j.als.2015.04.007

Conflict of Interest Statement: The authors declare that the research was conducted in the absence of any commercial or financial relationships that could be construed as a potential conflict of interest.

Copyright (c) 2017 Giri, Sen, Jun, Sukumaran and Park. This is an open-access article distributed under the terms of the Creative Commons Attribution License (CC BY). The use, distribution or reproduction in other forums is permitted, provided the original author(s) or licensor are credited and that the original publication in this journal is cited, in accordance with accepted academic practice. No use, distribution or reproduction is permitted which does not comply with these terms. 